\title{
BIOPHYSICAL MECHANISMS AND SCALING PROCEDURES APPLICABLE IN ASSESSING RESPONSES OF THE THORAX ENERGIZED BY AIR.BLAST OVERPRESSURES OR BY NON-PENETRATING MISSILES
}

I. G. Bowen, E. R. Fletcher, D. R. Richmond, F. G. Hirsch and C. S. White

Technical Progress Report on

Contract No. DA $-49-146-\mathrm{XZ}-372$

This work, an aspect of investigations dealing with the Biological Effects of Blast from Bombs, was supported by the Defense Atomic Support Agency of the Department of Defense.

(Reproduction in whole or in part is permitted for any purpose of the United States Government. )

Lovelace Foundation for Medical Education and Research Albuquerque, New Mexico 


\section{DISCLAIMER}

This report was prepared as an account of work sponsored by an agency of the United States Government. Neither the United States Government nor any agency Thereof, nor any of their employees, makes any warranty, express or implied, or assumes any legal liability or responsibility for the accuracy, completeness, or usefulness of any information, apparatus, product, or process disclosed, or represents that its use would not infringe privately owned rights. Reference herein to any specific commercial product, process, or service by trade name, trademark, manufacturer, or otherwise does not necessarily constitute or imply its endorsement, recommendation, or favoring by the United States Government or any agency thereof. The views and opinions of authors expressed herein do not necessarily state or reflect those of the United States Government or any agency thereof. 


\section{DISCLAIMER}

Portions of this document may be illegible in electronic image products. Images are produced from the best available original document. 


\section{FOREWORD}

This report contains the results of efforts to understand some of the biophysical mechanisms involved in the response of mammals to air-blast overpressures and to impact of non-penetrating missiles on the chest wall. One of the important aims of these studies is a more complete understanding of the response data obtained with mammals so that reasonable predictions can be made for the response of man.

The empirical data and interpretative material included in this report represent a portion of the results of an ongoing, long-term program aimed at clarifying the biological effects of blast-induced phenomena and assessing the consequences of exposure thereto.

This report was summarized on October 6, 1966, before a symposium on the Biological Effects of Air Blast at the National Academy of Sciences sponsored by the NAS-NRC Committee on Hearing, Bioacoustics, and Biomechanics, "CHABA". On October 11, 1966, that portion of the report concerned with the effects of air-blast overpressures was presented at the New York Academy of Sciences conference on Prevention of and Protection against Accidental Explosion of Munitions, Fuels, and other Hazardous Mixtures. The entire report was submitted for inclusion in the Annals of the New York Academy of Sciences. 


\section{ABSTRACT}

A mathematical model was described which was devised to study the dynamic response of the thorax of mammals to rapid changes in environmental pressure and to non-penetrating missiles impacting the rib cage near the mid-lateral point of the right or left thorax. Scaling procedures for similar animals were described relating, for a given degree of damage, the body mass of the animal to various parameters describing the exposure "dose."

Internal pressures computed with the model for a dog exposed at the end plate of a shock-tube were compared to those measured with a pressure transducer inserted in the esophagus down to the level of the heart.

Computed time-displacement histories of missiles following impact with the right side of the thorax were compared to those obtained experimentally by means of high-speed motion picture photography. High internal pressures predicted with the model for non-penetrating impact were compared to those obtained experimentally and theoretically for exposure to air blast.

Experimental data were presented arbitrarily assessing lung damage in animals struck by non-penetrating missiles (constant impact area) as a function of missile mass and impact velocity. These data were compared for several missile mass-velocity combinations with those computed using the mathematical model. Similarities in the dynamic responses of the thorax to air blast and to non-penetrating missiles were discussed. 


\section{ACKNOWLEDGMENTS}

The authors wish to acknowledge the work of Edward A. Spelich, Ray W. Albright, and Robert G. Babb in programming specific problems for numerical solution on a digital computer. Biological data used in the report were obtained through the efforts of Edward G. Damon, Charles S. Gaylord, Kabby Mitchell, Jr., William Hicks, Peter A. Betz, Donald E. Pratt, Vernon C. Goldizen, and Julian P. Henry.

Appreciation is expressed to Robert A. Smith, E. Joyce Blaine, and Martin J. Schortje, Jr. who prepared the illustrative material; and to Betty Lee Sanders and Martha E. Mitchell for editorial and secretarial assistance.

Though the immediate work of the present study was supported by the Defense Atomic Support Agency of the Department of Defense, the experimental data for the non-penetrating missile study were obtained from a program supported by the Division of Biology and Medicine of the U. S. Atomic Energy Commission. 
Foreword

Abstract

Acknowledgments

Introduction

The Mathematical Model.

Scaling Relations

Measured and Computed Intrathoracic Overpressures .

Sensitivity of Computed Response to Model Parameters

Computed Response to Free-Stream Exposure

Body Mass Scaling Applied to Step-Load Data

Combined Biological and Explosives Scaling

Analysis of Pressure-Duration Data.

Partial Impulse Analysis

Estimates of Man's Tolerance to Air Blast

Non-penetrating Missile Experiments .

Missile Time-Displacement Study . . .

Analysis of Non-penetrating Missile Data . . . . . . . 29

Summary

Appendix

\section{LIST OF TABLES}

No.

$1 \quad$ Nominal values of model parameters for a $10-\mathrm{kg}$

dog and body mass scaling factors . . . . 6

2

A summary of various estimates of man's

tolerance to air blast . . . . . . . . . 22

3

Data from non-penetrating missile experiments . . 30

\section{LIST OF FIGURES}

1 Mathematical model of the thorax to simulate fluidmechanical responses to rapid changes in environmental pressure and to non-penetrating missile impact with the chest wall $\cdot \dot{C}^{*} \cdot \dot{ }$

2 Intrathoracic overpressures measured and computed
for a $10-\mathrm{kg}$ dog exposed near the closed end of a shock tube to the indicated blast wave .

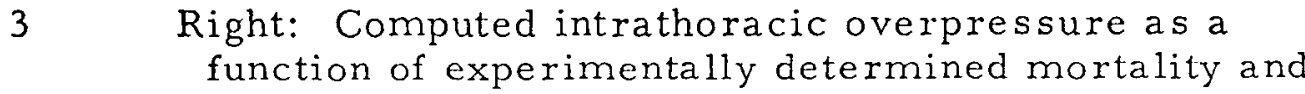
associated blast overpressures. Left: Sensitivity study showing variations in computed intrathoracic overpressure with changes in various model parameters 
No.

4 Computed response of a $10-\mathrm{kg}$ dog to free-stream exposure in a broadside standing posture to relatively

$\overline{1}$ "long" - and "short"-duration blast waves

Percent mortality for the indicated mammals exposed to step loads as a function of time between the steps (left) and scaled time (right).

Blast situations predicted by the scaling equations to produce the same biological response in similar animals

A test of the scaling procedures.illustrated in FIGURE 6

Average lung volume per body mass and average lung density as functions of body mass for 8 species of mammals. Data from Crosfill and Widdicome (1961)

Pressure-duration and partial impulse analyses of animal tolerance data scaled to a body mass of $70-\mathrm{kg}$ and to an ambient pressure of $14.7 \mathrm{psi}$. The experimental data were obtained by exposing animals near a reflecting surface to shock-tube and high-explosive generated blast waves. Experimental arrangement for the non-penetrating missile studies

A comparison of computed and measured displacement parameters for non-penetrating missile experiment $\mathrm{M} 50$

A comparison of computed and measured displacement parameters for non-penetrating missile experiments M65 and M66

Computed intrathoracic overpressures for nonpenetrating missile experiment M50 .

A comparison of the masses of the right and left lungs of dogs used in the non-penetrating missile experiments. See TABLE

Results of a general analysis of the non-penetrating missile experiments. The lines of constant peak intrathoracic overpressure were computed with 
BIOPHYSICAL MECHANISMS AND SCALING PROCEDURES APPLICABLE IN ASSESSING RESPONSES OF THE THORAX ENERGIZED

BY AIR-BLAST OVERPRESSURES OR BY

NON - PENETRATING MISSILES

I. G. Bowen, E. R. Fletcher, D. R. Richmond,

F. G. Hirsch and C. S. White

$\underline{\text { Introduction }}$

During the Second World War, Schardin (1950) in Germany showed that the mortality curves for animals exposed to air blast produced by high explosives were similar to characteristic destruction curves for window glass mounted in suitable frames and exposed to similar blast waves; i.e., he demonstrated for both glass panes and for animals that the criterion for damage due to exposure to blast waves of "short" duration is overpressure impulse, or momentum, while overpressure per se is the determining factor if the duration of the wave is "long. "The destruction curve for window panes was not surprising since the panes clearly were spring-mass systems which would break at a critical deflection and the "short" and "long" describing the duration of the waves could be related to the natural period of the oscillating system. Nevertheless, Schardin was unwilling to state unequivocally that the animal body acted as a spring-mass system when exposed to blast waves. He did write that "very definite phenomena must be responsible for the killing of an animal by shock wave. " It was some time later that Clemedson and Jönsson (1961) and Richmond et al. (unpublished data)* measured intrathoracic pressures in animals subjected to air blast and thus produced experimental evidence of an oscillating system.

The mathematical model presented herein is a revision of one previously developed to simulate the thoraco-abdominal system for studies in blast biology (Bowen et al., 1965). The principal changes incorporated into the revised model are (1) individual consideration of the two lungs, each possessing a chest-wall piston and separated from each other by a piston representing the mediastinal tissue between the lungs, (2) provision for loading not only by external pressure changes but also by impact of a non-penetrating missile with one chest wall, (3) deletion of a piston representing the abdomen. The abdominal piston was omitted not just for simplicity but because reported acoustic data indicates 1965).

* Data for rabbits were used in a previous report (Bowen et al. , 
that the motion of the abdomen is much slower than that of the chest wall, the resonant frequency of the abdomen being approximately $1 / 20$ of that of the chest (von Gierke, 1964).

The model study can be divided into two distinct categories. The first is aimed at a more complete understanding of the gross biophysical mechanisms taking place within the thorax subjected to blast or missileproduced trauma, this being accomplished through numerical solution of the model for various situations. The second is application of the derived scaling relations (assuming similarity of mammalian species) to experimental data making it possible (1) to infer similarity or dissimilarity of various species, and (2) to project, or scale, the experimental results obtained with one or more species to be applicable to the human case.

The Mathematical Model

The mathematical model illustrated in FIGURE 1 is a modified spring-mass system designed to simulate the gross fluid-mechanical responses of the thorax to rapid changes in environmental pressure or to non-penetrating impact of a missile with the chest. Note that the motions of the three pistons (the outside ones representing the chest walls and the middle one the tissue between the lungs) are constrained by springs simulating tissue elasticity and by dash pots simulating frictional effects. The simple orifices of each of the chambers are used to simulate the more complex airways of the mammal.

Provision was made to load each of the chest-wall pistons with arbitrary pressure-time profiles, $P_{1}^{\prime}(t)$ and $P_{2}^{\prime}(t)$, and the two orifices can be loaded with a third function, $F_{3}{ }^{\prime}(t)$. For non-penetrating missile studies, one of the chest-wall pistons can be activated with the impact of a missile with specified mass and initial velocity. The spring constant $\mathrm{K}_{4}$ and damping factor $\mathrm{J}_{4}$ associated with missile impact a re actually parameters mostly determined by properties of the chest wall, e.g., area density, elasticity.

Equations describing the model were derived and programmed for solution on a digital computer, the general procedures being simila $r$ to those previously reported (Bowen et al., 1965). The new program, however, incorporates a more accurate air flow analysis and, in general, is more versatile.*

\section{Scaling Relations}

Scaling equations appropriate to blast biology were derived using the technique of dimensional analysis and the assumption of similarity of

*A more complete description of model program will be given in a subsequent report. 


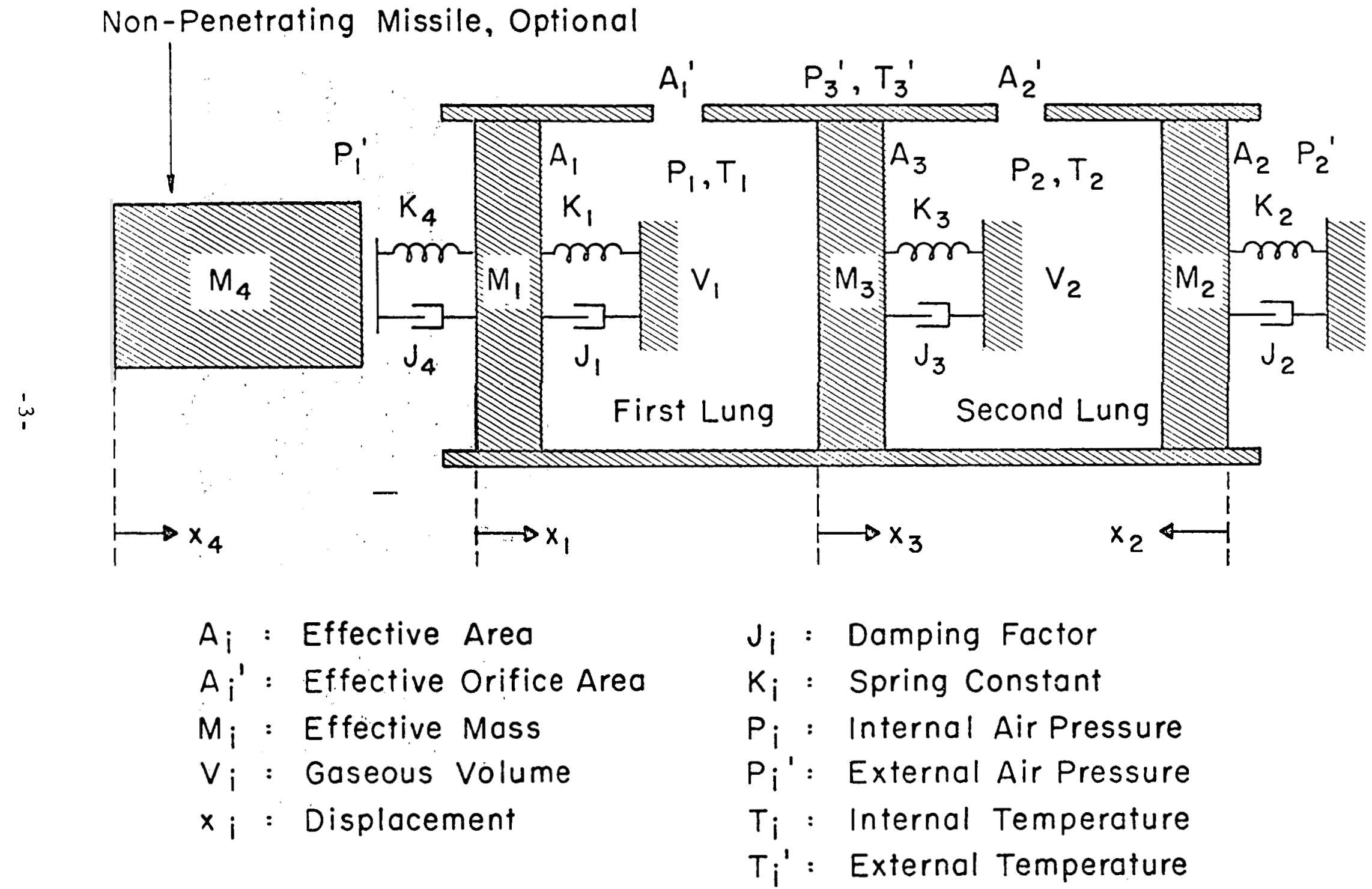

Figure 1. Mathematical model of the thorax to simulate fluid-mechanical responses to rapid changes in environmental pressure and to non-penetrating missile impact with the chest wall. 
mammalian species; i.e., similarity of shape of the body structure and equivalent distributions of tissue mass and elasticity (Bowen et a1., 1965). The equations are summarized below:

$$
\begin{aligned}
& \underline{R}=K_{1} \\
& \text { and } \\
& \mathrm{P}^{\prime} P_{0}=K_{2} \\
& \text { if } \\
& \mathrm{P}_{0}^{1 / 2} / \mathrm{m}^{1 / 3}=\mathrm{K}_{3} \\
& \text { and } \\
& \mathrm{P}^{\prime / P_{0}}=\mathrm{K}_{4}
\end{aligned}
$$

K's : Constants

R : Any nondimensional index of biological response, e.g., percent mortality or percent increase in Iung mass.

$\dot{P} \quad$ : Any characteristic pressure of the pulse occurring in the lungs, such as peak pressure.

$P_{0} \quad$ : Ambient pressure.

$t$ : Any characteristic time of blast waves of similar shape, or of the internal pressure waves; e.g., duration of the blast wave, time to reach maximum intrathoracic overpressure.

m : Body mass of similar animals.

$\mathrm{P}^{\prime} \quad$ : Any characteristic pressure of blast waves of similar shape, e.g., peak pressure.

In order to derive the simplified scaling equations listed above, it was necessary to make. certain approximations - the most significant of which involves the damping factor $J$ and the ambient pressure $P_{0}$. The more accurate scaling requires that $\mathrm{J}$ be proportional to $P_{0}^{1} / 2$ Since, in fact, $J$ does not increase with $P_{O}$, the ratio $P^{\prime} / P_{O}$ for a given biological response would be expected to decrease as, the ambient pressure increases. This effect, although not great, has been noted experimentally (Damon et al., 1963 and 1966a).

Since much of the experimental data in primary blast biology is obtained with high explosives, it is worthwhile to combine the biological and weapons scaling procedures. In conventional weapons scaling, 


$$
\mathrm{P}^{\prime} / \mathrm{P}_{\mathrm{o}}=\mathrm{K}_{4}
$$

and

$t \mathrm{P}_{\mathrm{o}}^{1 / 3} / \mathrm{w}^{1 / 3}=\mathrm{K}_{5}$

if

$$
\mathrm{RP}_{\mathrm{o}}^{1 / 3} / \mathrm{W}^{1 / 3}=\mathrm{K}_{6}
$$

where $W$ and $R$ are weapon yield and range, or distance, from the explosion, respectively, and the $\mathrm{K}^{\prime}$ s are constants. Thus, combining Eqs. (3) and (5),

$$
\mathrm{W} \mathrm{P}_{\mathrm{o}}^{1 / 2} / \mathrm{m}=\mathrm{K}_{3}^{3} / \mathrm{K}_{5}^{3}=\mathrm{K}_{7}
$$

and combining Eqs. (3), (5), and (6),

$$
\mathrm{RP}_{\mathrm{o}}^{1 / 2} / \mathrm{m}^{1 / 3}=\mathrm{K}_{3} \mathrm{~K}_{6} / \mathrm{K}_{5}=\mathrm{K}_{8} \text {. }
$$

An extension of the analys is to include non-penetrating missiles results in the following:

$$
\begin{aligned}
& \mathrm{v}_{0} / \mathrm{P}_{0}^{1 / 2}=\mathrm{K}_{9} \\
& \mathrm{M} / \mathrm{m}=\mathrm{K}_{10} \\
& \mathrm{~A} / \mathrm{m}^{2 / 3}=\mathrm{K}_{11}
\end{aligned}
$$

$v_{0}:$ Impact velocity of the missile.

M : Mass of the missile.

A : Area of impact of the missile.

\section{Measured and Computed Intrathoracic Overpressures}

Parameters listed in TABLE 1 for a $10-\mathrm{kg}$ dog were used in the model to simulate an experiment in which a dog was placed at the endplate of a shock tube, as illustrated in FIGURE 2, and subjected to a reflected blast wave of about 48-psi overpressure (Richmond et al., unpublished data). A pressure transducer was placed in the esophagus near the bifurcation of the trachea to measure intrathoracic pressure versus time.

Although side-on overpressure was measured near the end-plate, it was ne.cessary for the model study to make different estimates of the pressure profiles loading the right and left chest walls. Criteria used for this purpose were obtained, in part, from a model study in which rectangular blocks were loaded with blast waves of various magnitudes (Iwanski et al., 1957). The thorax of the dog was approximated as a 
TABLE 1. NOMINAL VALUES OF MODEL PARAMETERS FOR A 10-KG DOG AND BODY MASS SCALING FACTORS* $\mathrm{m}$ : body mass, $\mathrm{kg}$

\begin{tabular}{|c|c|c|c|c|}
\hline & \multicolumn{2}{|c|}{ 10-kg Dog } & \multicolumn{2}{|c|}{ Scaling Factors } \\
\hline & Blast & Missile & Blast & Missile** \\
\hline$A_{1}, \quad \mathrm{~cm}^{2}$ & 131 & 90 & $(\mathrm{~m} / 10)^{2 / 3}$ & \\
\hline $\mathrm{A}_{2}, \quad \mathrm{~cm}^{2}$ & 94.6 & 94.6 & $(\mathrm{~m} / 10)^{2 / 3}$ & $(\mathrm{~m} / 10)^{2 / 3}$ \\
\hline $\mathrm{A}_{3}^{2}, \quad \mathrm{~cm}^{2}$ & 59.1 & 59.1 & $(\mathrm{~m} / 10)^{2 / 3}$ & $(\mathrm{~m} / 10)^{2 / 3}$ \\
\hline $\mathrm{M}_{1}$ & 168 & 90.5 & $(\mathrm{~m} / 10)$ & $(\mathrm{m} / 10)^{1 / 3}$ \\
\hline $\mathrm{M}_{2}$ & 122 & 122 & $(\mathrm{~m} / 10)$ & $(\mathrm{m} / \mathrm{lo})$ \\
\hline$M_{3}, \quad g$ & 72.4 & 72.4 & $(\mathrm{~m} / 10)$ & $(\mathrm{m} / 10)$ \\
\hline $\mathrm{J}_{1}, \quad$ dyne-sec/cm & $1.10 \times 10^{5}$ & $3.09 \times 10^{4}$ & $(\mathrm{~m} / 10)^{2 / 3}$ & $(\mathrm{~m} / 10)^{2 / 3}$ \\
\hline $\mathrm{J}_{2}, \quad$ dyne-sec/cm & $8.02 \times 10^{4}$ & $8.02 \times 10^{4}$ & $(\mathrm{~m} / 10)^{2 / 3}$ & $(\mathrm{~m} / 10)^{2 / 3}$ \\
\hline $\mathrm{J}_{3}, \quad$ dyne-sec/cm & $1.56 \times 10^{4}$ & $1.56 \times 10^{4}$ & $(\mathrm{~m} / 10)^{2 / 3}$ & $(\mathrm{~m} / 10)^{2 / 3}$ \\
\hline $\mathrm{K}_{1}$, dyne/cm & $3.00 \times 10^{5}$ & $8.76 \times 10^{4}$ & $(\mathrm{~m} / 10)^{1 / 3}$ & $(\mathrm{~m} / 10)^{1 / 3}$ \\
\hline $\mathrm{K}_{2}, \quad$ dyne $/ \mathrm{cm}$ & $2.17 \times 10^{5}$ & $2.17 \times 10^{5}$ & $(\mathrm{~m} / 10)^{1 / 3}$ & $(\mathrm{~m} / 10)^{1 / 3}$ \\
\hline $\mathrm{K}_{3}, \quad$ dyne $/ \mathrm{cm}$ & $1.11 \times 10^{5}$ & $1.11 \times 10^{5}$ & $(\mathrm{~m} / 10)^{1 / 3}$ & $(\mathrm{~m} / 10)^{1 / 3}$ \\
\hline $\mathrm{V}_{1}, \quad \mathrm{~cm}_{3}^{3}$ & 150 & 150 & $(\mathrm{~m} / \mathrm{lo})$ & $(\mathrm{m} / 10)$ \\
\hline $\mathrm{V}_{2}, \quad \mathrm{~cm}^{3}$ & 108 & 108 & $(\mathrm{~m} / 10)$ & $(\mathrm{m} / 10)$ \\
\hline$A_{1}^{\prime}, A_{2}^{\prime} \mathrm{cm}^{2}$ & $2.19 \times 10^{-2}$ & $2.19 \times 10^{-2}$ & $(\mathrm{~m} / 10)^{2 / 3}$ & $(\mathrm{~m} / 10)^{2 / 3}$ \\
\hline $\mathrm{J}_{4}, \quad$ dyne-sec/cm & & $2.27 \times 10^{5}$ & & $(\mathrm{~m} / 10)^{2 / 3}$ \\
\hline $\mathrm{K}_{4}, \quad$ dyne $/ \mathrm{cm}^{1.63}$ & & $5.66 \times 10^{5}$ & & $(\mathrm{~m} / 10)^{1 / 3}$ \\
\hline
\end{tabular}

* Methods used to evaluate the model parameters are described in the Appendix.

**In the experiments the impact area of the missile was not scaled with the body mass of the dog as required by Eq. (11); thus, most of the remaining scaling relations for missile impact are uncertain. 


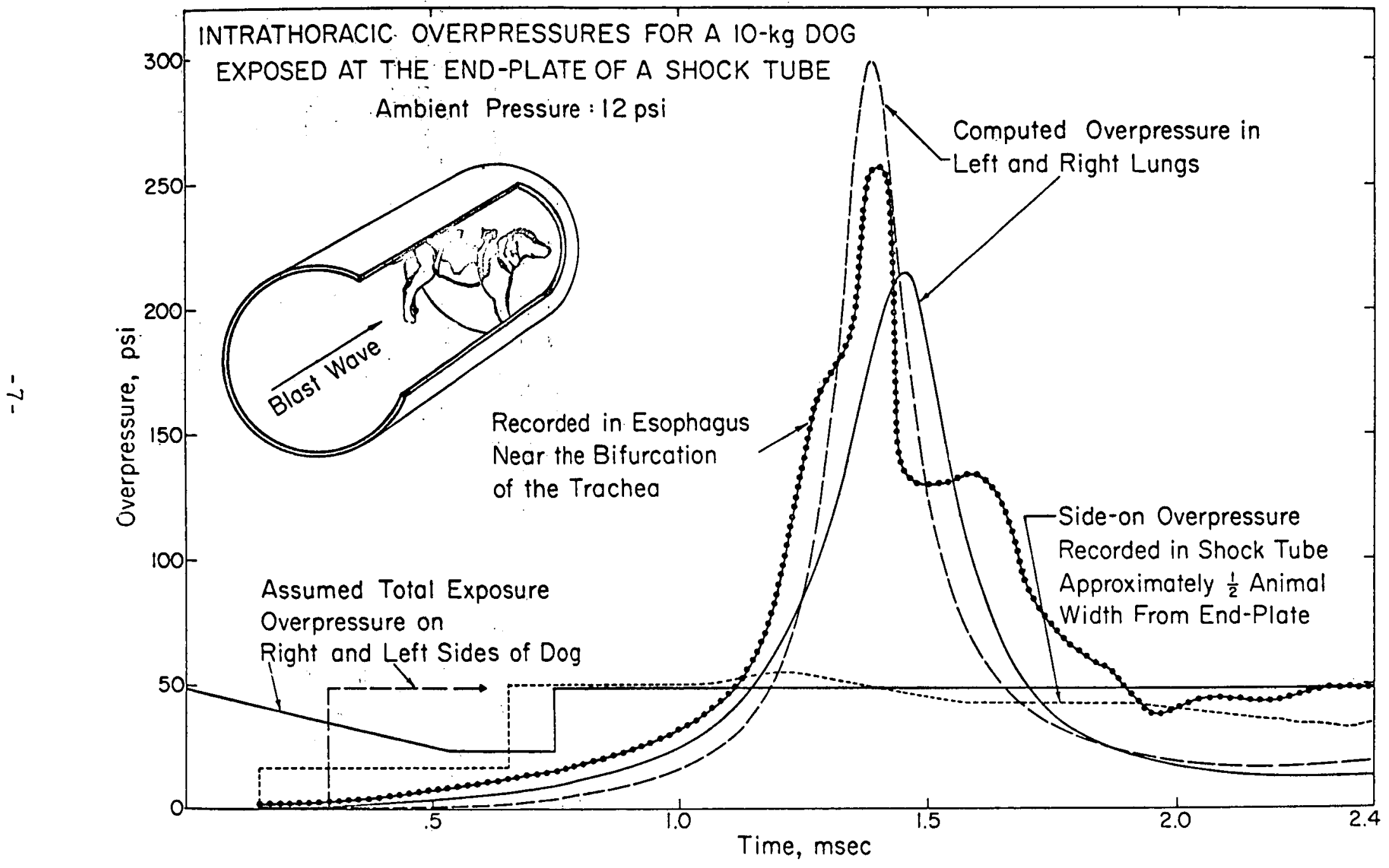

Figure 2. Intrathoracic overpressures measured and computed for a $10-\mathrm{kg}$ dog exposed near the closed end of a shock tube to the indicated blast wave. 
long block 7.15 inches high and 5.84 inches wide, perpendicular and parallel to the direction of shock travel, respectively, with flow occurring over and under the block.

Note in FIGURE 2 that the right side of the thorax is assumed to be loaded initially with the full reflected overpressure which decays because of flow to the incident overpressure plus dynamic pressure. A short time later the reflected blast wave arrives from the end-plate, after which the thorax is completely engulfed in stagnated air. The left side of the thorax is as sumed to be loaded instantaneously with the re flected overpressure when the incident wave reaches the end-plate.

Even though the right lung was loaded first, because of the steplike nature of the loading function the computed peak intrathoracic overpressure was lower, and later in occurring, in this lung than in the left one. This result is in agreement with observations that similarly exposed mammals received more damage in the lungs nearest the end-plate than in the other (Richmond et al., unpublished data).

The intrathoracic overpressure measured in the esophagus peaked at $257 \mathrm{psi}$ in about the same time as that computed for the left lung. The peak overpressure computed for the left lung was higher (298 psi) and that for the right lung was lower (214 psi) than the measured value, pointing to uncertainties in the interpretation of intrathoracic pressures measured in the esophagus between the lungs.

\section{Sensitivity of Computed Response to Model Parameters}

Because of the complex nature of the interactions of various mechanisms involved in the implosion process, it is very difficult to predict the significance of various animal parameters on the response of the animal to blast. In the study described below, peak intrathoracic overpressures were computed for one blast situation, individually varying six sets of model parameters. The results are compared with peak intrathoracic overpressures computed, using nominal parameters, for several blast waves for which animal response has been determined experimentally.

The blast situation used is the same one described in the last section for a 10-kg dog placed at the end-plate of a shock tube. FIGURE 3 (left) contains a plot of the average computed peak intrathoracic overpressure as a function of the indicated parameters varying between 60 and 140 percent of their nominal values listed in TABLE 1 . These results can be related to the intrathoracic overpressures shown on the right side of FIGURE 3 computed, using nominal animal parameters, for blast waves corresponding to various levels of 24-hr mortality (Richmond et al., 1966a).

The computed results show that intrathoracic pressures are most sensitive to changes in the damping factors; a 40 percent increase in the $\mathrm{J}$ parameters, representing an increased frictional loss, results in a decrease in predicted mortality from 50 to 22 percent. An increase in 
10-kg DOG AT THE END-PLATE OF A SHOCK TUBE

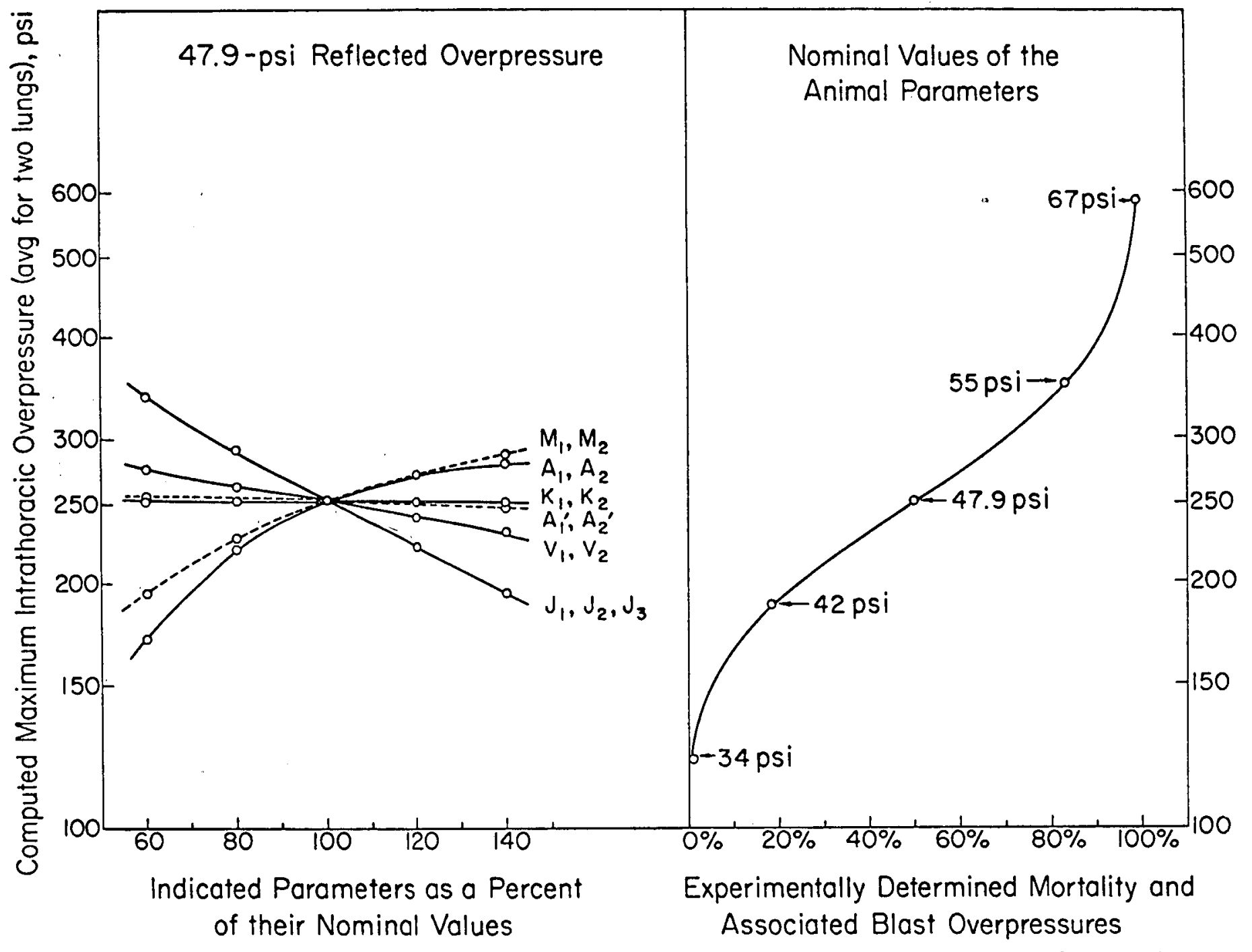

Figure 3. Right: Computed intrathoracic overpressure as a function of experimentally determined mortality and as sociated blast overpressures. Left: Sensitivity study showing variations in computed intrathoracic overpressure with changes in various model parameters. 
volume increases the distance of piston travel to achieve a given volume change, resulting in increased frictional, or viscous, losses and reduced internal pressures. Conversely, an increase in piston area reduces the distance traveled and results in an increased internal pressure. An increase in mass results in the piston attaining the same momentum at a lower velocity. Since frictional forces are proportional to velocity, the resulting internal pressures are higher.

It is noteworthy that the response of the model is practically unaffected by \pm 40 percent changes in the spring constant and orifice area parameters. This would suggest (a) that the structural strength of the thorax is small relative to the forces involved in blast and (b) that insignificant amounts of air a re transported to and from the lungs during the short times involved in the blast experience.

\section{Computed Response to Free-Stream Exposure}

The blast situation examined in the previous sections was that of the animal placed at the end-plate of a shock tube. Consider now the situation where the animal is in the free-stream with its right side facing the oncoming blast wave. Theoretical studies of the free-stream situation were made with the $10-\mathrm{kg}$ dog parameters (TABLE 1) and blast waves of "long" and "short" duration. Loading of the right and left sides of the thorax was estimated in a manner similar to that previously described for a dog at the end-plate of the shock tube using the criteria of Iwanski et al. (1957).

Four blast waves of "long" duration (no pressure decay in the first three $\mathrm{msec}$ ) were used whose incident overpressure plus dynamic pres sure equal $47.9,50,52$, and 54 psi (ambient pressure: 12 psi). The loading functions estimated for the 47.9-psi wave and the computed intrathoracic overpressures are plotted in FIGURE 4 (left). The peak lung pressures computed for the remaining blast waves are shown in the same graph. Note that blast waves with incident plus dynamic pressures between 52 and 54 psi result in approximately the same average peak lung pressures as that computed for 50 percent mortality ( 250 psi) shown in FIGURE 3. It is also noteworthy that the computed pressures for the left lung are somewhat higher than those for the right lung even though the assumed blast loading for the right lung is considerably higher.

The "short"-duration blast wave has an incident overpressure of $48 \mathrm{psi}$ and duration of two $\mathrm{msec}$, the shapes of the overpressure and dynamic pressue waves being determined from numerical studies of TNT blast waves (Brode, 1957). In this instance, the estimated loading for the right lung is much greater than that for the left and consequently, the right lung is subjected to higher compression. The average of the peak overpressure computed for the right and left lung is 252 psi, approximately that shown in FIGURE 3 for 50 percent mortality.

No direct comparison can be made at the present time between the computed results of this section and published experimental data. However, unpublished results of free-stream experiments, referred to by 


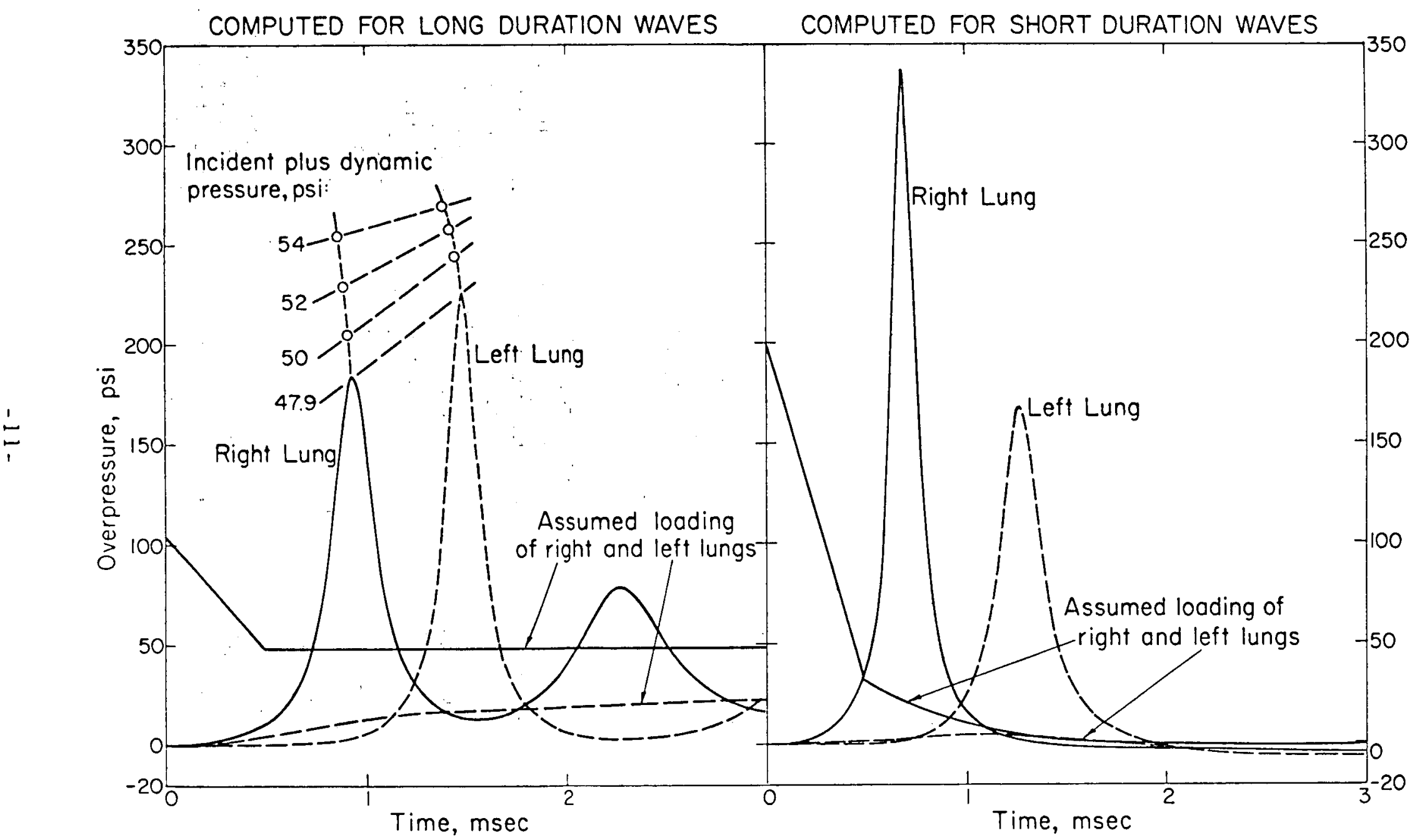

Figure 4. Computed response of a $10-\mathrm{kg}$ dog to free-stream exposure in a broadside standing posture to relatively "long"- and "short"-duration blast waves. 
Richmond et al. (1966a), are pertinent to the problem. Guinea pigs were exposed broadside at the end-plate of a shock tube and in various orientations in the free-stream, i.e., no end-plate. For broadside prone exposures in the free-stream, it was reported that the 50 percent lethal condition was attained if the sum of the incident overpressure and the dynamic pressure was approximately equal to the reflected overpressure killing 50 percent of the animals exposed at the end-plate. The computed results for the "long"-duration wave (FIGURE 4, left) are approximately consistent with this criteria.

\section{Body Mass Scaling Applied to Step-Load Data}

Small animals were placed in wide-mesh cages and exposed side-on at the end-plate of a shock tube and at various distances up to 12 inches away from it (Richmond et al., 1959). An attempt was made to produce incident and reflected shock waves of constant magnitude by using approximately the same overpressure in the compression chamber. The reflected overpressures measured for the entire series of shots varied between 48 and 56 psi, the average being 52.1 psi. The corresponding average of the incident shock overpressures was between 17 and 18 psi, spanning the 17.2-psi shock that theoretically would produce a reflected wave of 52.1 psi for the conditions of perfect reflection at normal incidence and an ambient pressure of 12 psi.

Animal mortality was reported for the mouse, rat, guinea pig, and rabbit as a function of distance from the end-plate. All animals placed against the end-plate were killed but the mortality showed a decline as the distance from the end-plate was increased - the distance necessary to afford a given degree of protection being greater for the larger animals than that for the smaller ones.

The experimental mortality data are plotted in FIGURE 5 (left) as a function of time between incident and reflected shocks using the center of the animal cage as the reference point. As noted above, the magnitude of the pressure steps were, on the average, the same for the entire series of experiments; therefore, the scaling relationship expressed in Eq. (4) is satisfied. According to Eq. (3) the time scaling would be accomplished if the time between the steps were proportional to the cube root of body mass. These concepts are tested in FIGURE 5 (right) in which mortality is plotted as a function of scaled time. Although discrepancies are observed in the guinea pig response to the blast waves with the longer times between steps, the data in general can be represented bv a single line instead of one for each species.

A significant result of the analysis described above is that it supplies evidence of similarity of the four species of animals insofar as response to blast exposure is concerned. However, no indication was given of the biophysical mechanisms involved in the step-load experience. A previous study (Bowen et al., 1965) indicated that the animal's response to the first step effectively establishes a higher local ambient pressure which helps to protect it from the second step. Qualitatively, this concept is in agreement with the ambient pressure scaling relation expressed in Eq. (4). 
$t_{s}:$ Time between incident (17.2psi) and reflected (52.1 psi) shocks using the center of the animal cage as the reference point

$m$ : Animal body mass

- Mouse, $\Delta$ Rat, $\square$ Guinea Pig, $\diamond$ Rabbit

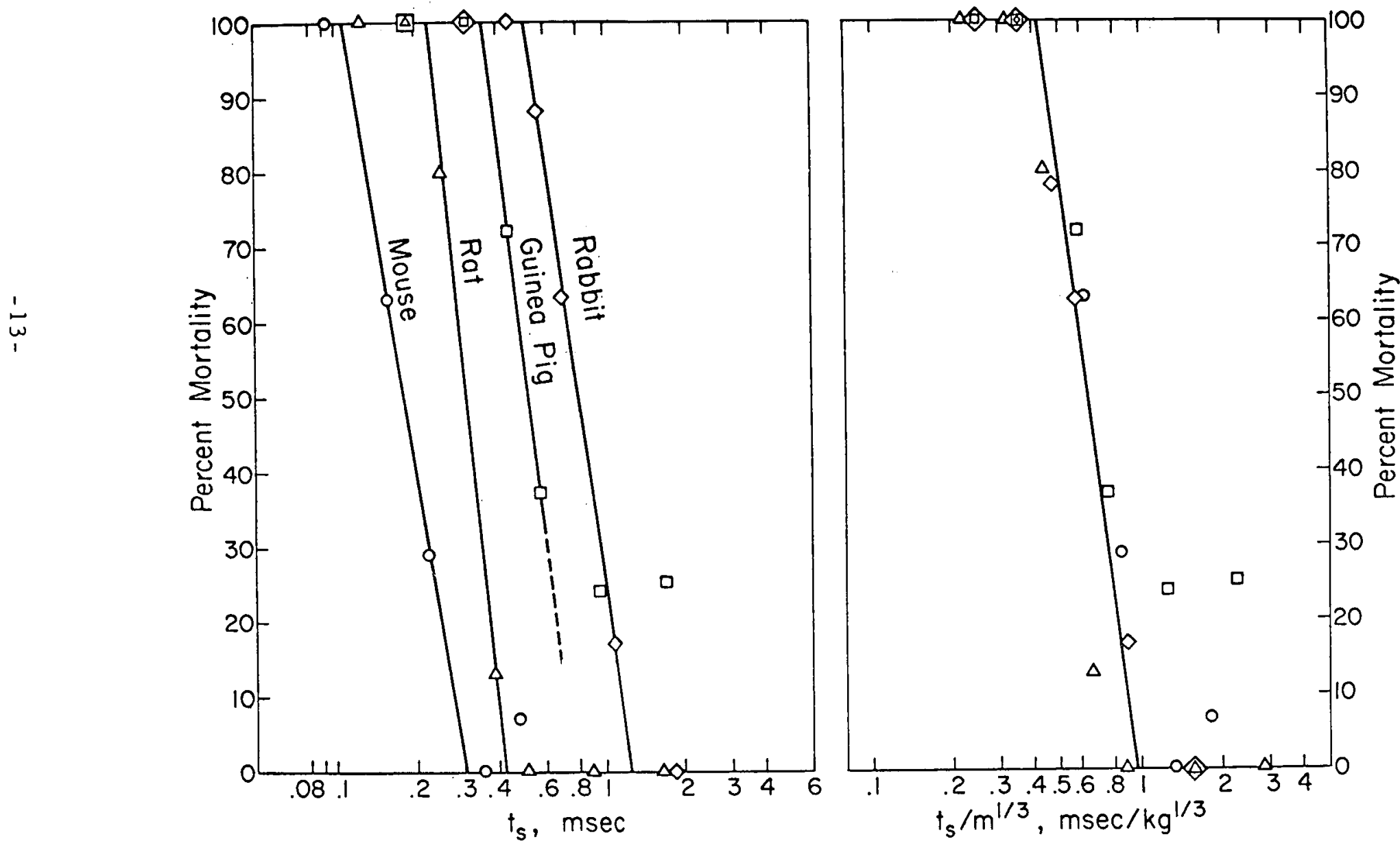

Figure 5. Percent mortality for the indicated mammals exposed to step loads as a function of time between the steps (left) and scaled time (right). 
Combined Biological and Explosives Scaling

The scaling relations of Eqs. (7) and (8) are graphically illustrated in FIGURE 6 for overhead charges and a given ambient pressure. Note that all linear dimensions of the second and third blast situations portrayed are increased by factors of two and three, respectively, of the corresponding ones in the first case. The peak reflected overpressures experienced by each of the three animals are the same, but the durations of the blast waves are proportional to the animal body length or to the cube root of the body mass.

To test the validity of the scaling procedures illustrated,in FIGURE 6, high-explosive mortality data (Richmond and White, 1962, and Richmond et al., unpublished data) were translated into heights of burst and TNT charge weights using blast data for Pentolite (Goodman, 1960) assuming that $1.1 \mathrm{lbs}$ of TNT is equivalent to $1 \mathrm{lb}$ of Pentolite. The computed charge weights and the heights of burst were then normalized to animal body mass and to the cube root of body mass, respectively. The resulting data plotted in FIGURE 7 indicate that the points for the small animals (mouse, rat, guinea pig, and rabbit) determine one line and that those for the larger animals (monkey, dog, goat, sheep, and swine) determine another.

Lines of constant scaled impulse and of constant maximum overpressure are also plotted in FIGURE 7. As noted by Schardin (1950) for single species of mammals, each of the tolerance curves for the grouped species approaches a constant scaled impulse for small charges, and durations, and approaches a constant maximum overpressure for larger charges.

The above indicates a degree of animal similarity within each of two groups. Published data (Crosfill and Widdicombe, 1961) which are plotted in FIGURE 8 present some evidence of the differences between the two groups of species. Note that the lung volumes, normalized to body mass, of the larger species (monkey, cat, dog, and man) are approximately three times as large as those for the smaller species (mouse, rat, guinea pig, and rabbit). "On the other hand, the densities of the lungs of the larger species are only about one-half those of the smaller.

Analysis of Pressure-Duration Data

Experimental data used in this study were obtained by exposing experimental animals near a reflecting surface to shock-tube and highexplosive generated blast waves (Richmond and White, 1962; Richmond et al., 1966; Damon et al., 1966b; Richmond et al., unpublished data). The reflected overpressure and wave duration data reported are applicable to 50 percent mortality in 24 hours and to an ambient pressure of 12 psi. 


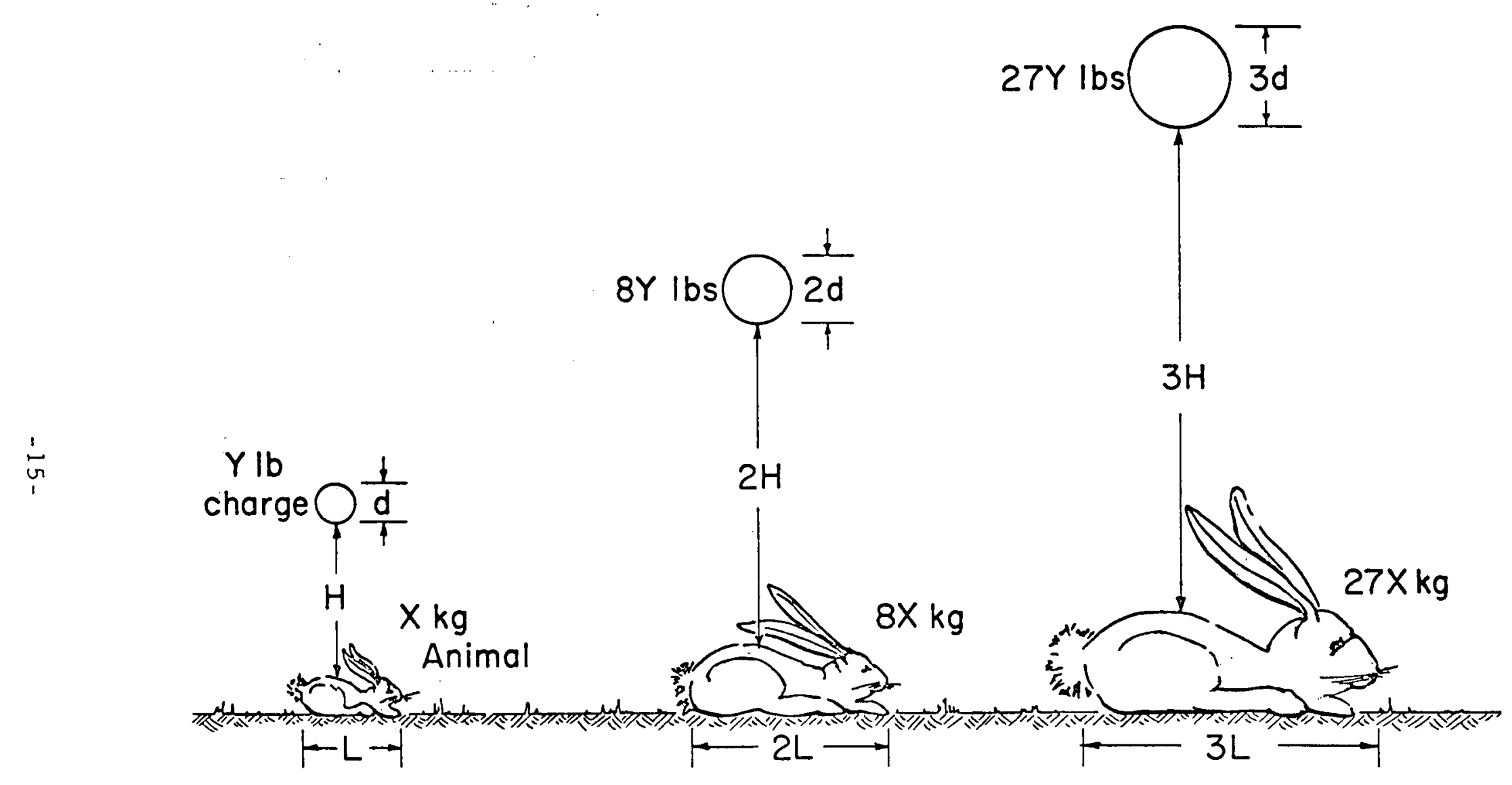

BLAST CONDITIONS PRODUCING EQUAL BIOLOGICAL RESPONSE TO SIMILAR ANIMALS WITH MASSES OF $X, 8 X$, AND $27 X \mathrm{KG}$

Figure 6. Blast situations predicted by the scaling equations to produce the same biological response in similar animals. 


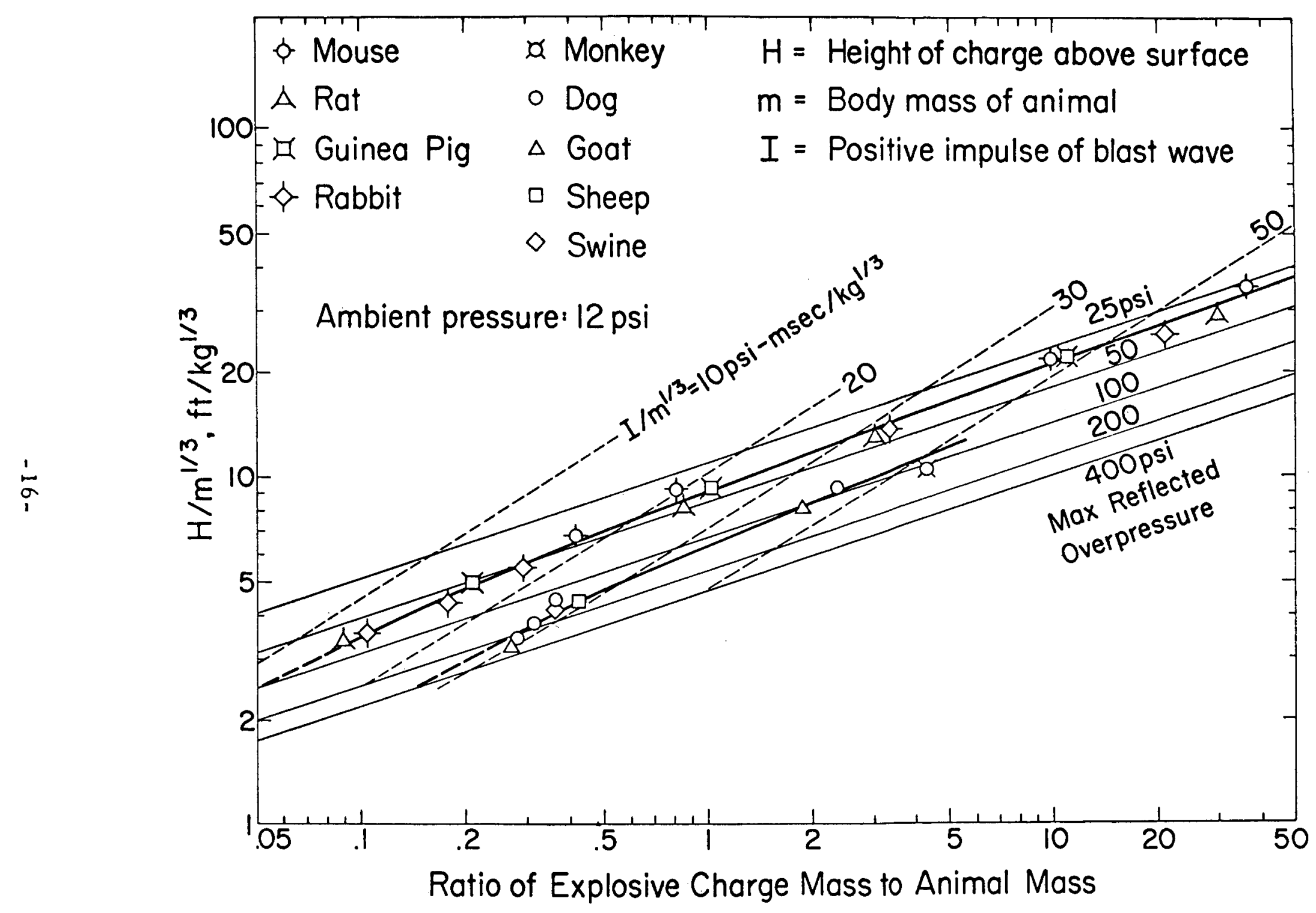

Figure 7. A test of the scaling procedures illustrated in FIGURE .6. 

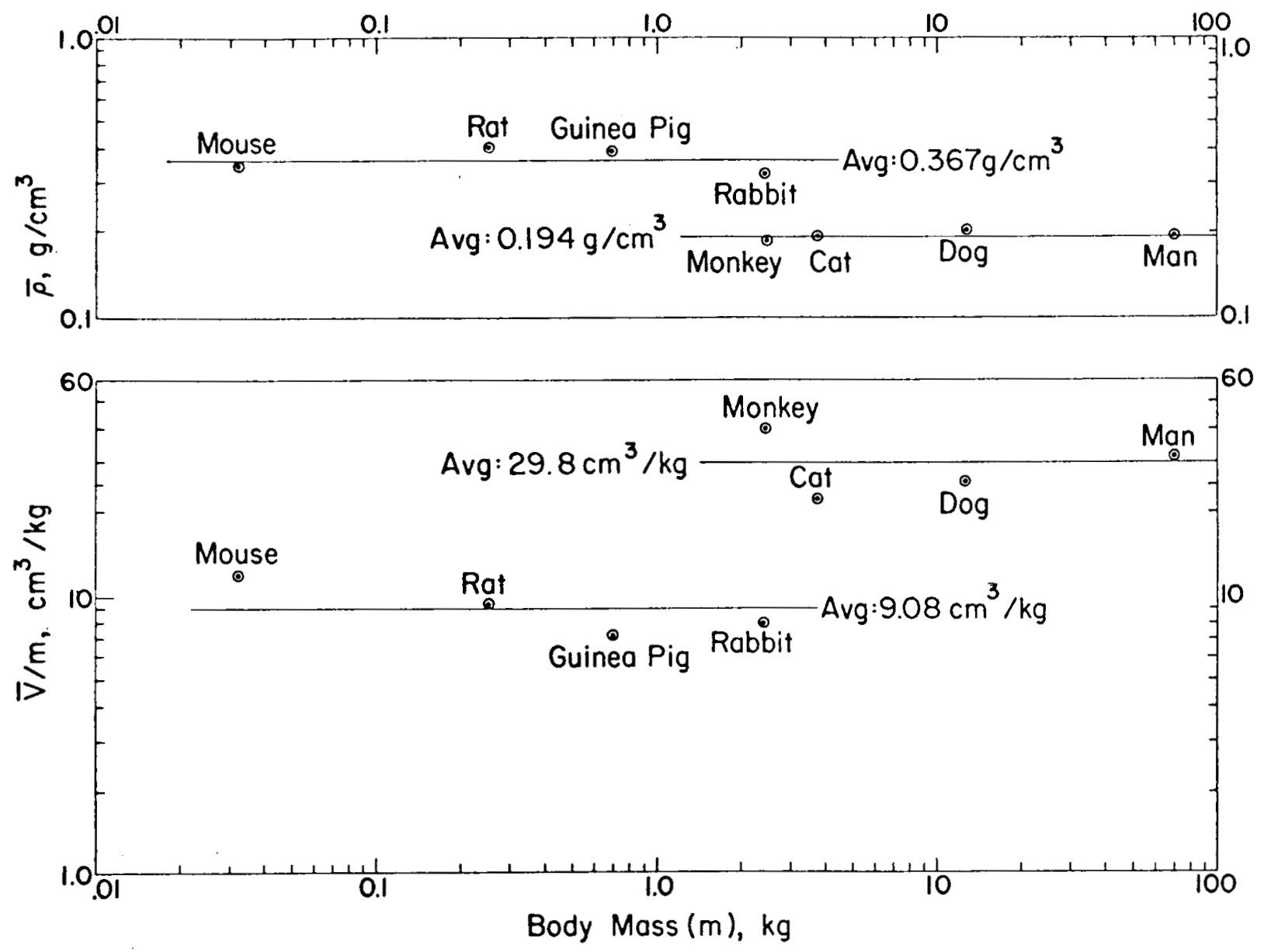

$$
\begin{aligned}
& \bar{V} / m=(F R C+1 / 2 T V) / m \\
& \bar{V}: \text { Avg gaseous volume of lungs } \\
& m: \text { Body mass } \\
& \text { FRC } \text { Functional residual capacity } \\
& T V: \text { Tidal volume } \\
& M: \text { Mass of lungs }
\end{aligned}
$$$$
\bar{\rho}=M /(\bar{V}+v)
$$$$
\bar{\rho}: \text { Avg density of lungs }
$$$$
v \text { : Volume of lung tissue * }
$$$$
\text { * Density of lung tissue assumed to }
$$$$
\text { be } 1.0 \mathrm{~g} / \mathrm{cm}^{3}
$$

Figure 8. Average lung volume per body mass and average lung density as functions of body mass for 8 species of mammals. Data from Crosfill and Widdicombe (1961). 
Equations (3) and (4) were used to scale the individual overpressureduration combinations obtained in the experimental studies to be applicable to a $70-\mathrm{kg}$ mammal and to 14.7-psi ambient pressure. The loga $\mathrm{rithm}$ of maximum overpressure was then plotted as a function of reciprocal duration of the blast wave as illustrated in FIGURE 9. The plotted datum points tend to fall along straight lines separating the mammalian species into two groups: (1) mouse, hamster, rat, guinea pig, and rabbit; (2) cat, monkey, dog, goat, sheep, swine, and cattle. Although more species are included in the present study, the group divisions are consistent with those previously shown in FIGURE 7 for the high-explosive experiments.

Results of least-squares analysis are presented in FIGURE 9 for each group of species. Although considerable scatter appears in the data of both groups, the small-animals points show more internal consistency than do those for the large-animal group. The standard error of estimate in overpressure is approximately 10.6 percent for the small animals and 12. 4 percent for the large. Although a judgment is premature at this time, the single monkey point suggests that primates may have higher blast tolerance than other Orders of Mammalia tested.

\section{Partial Impulse Analysis}

Maximum compression of the lungs typically occurs very soon after arrival of the blast wave as illustrated in FIGURE 2 for a $10-\mathrm{kg}$ dog. The question now to be investigated is whether or not the data presented in FIGURE 9 can be used to estimate a characteristic time, $t_{0}$, during which the blast wave causes the most significant response of the thorax, maximum compression. The second and more important phase of the problem, however, is to determine an invarient parameter, and its magnitude, with which to describe the blast wave during time to. As mentioned in the introduction (Schardin, 1950) and illustrated in FIGURE 7, the important blast parameter for waves of "short" duration is impulse. Thus, a reasonable procedure would be to relate the magnitude of this impulse to that of the impulse occurring during time, $t_{0}$, for blast waves of any duration. The latter has been called partial impulse, Io.

The trial-and-error methods used to test the above hypothesis are not dependent on a prior knowledge of the magnitude of the impulse applicable to "short"-duration waves. It is necessary, however, to use data for a wide range of durations.

The first step in the procedure was to approximate the pressuretime relation for all blast waves with

$$
P=P_{m}\left(1-t / t_{+}\right) \exp \left(-n t / t_{+}\right)
$$

where $P$ is overpressure, $P_{m}$ maximum overpressure, $t$ time, $t_{+}$duration of the wave, and $n$ is a function of $P_{m}$ and ambient pressure. Values of $n$ were determined from data for Pentolite (Goodman, 1960). 


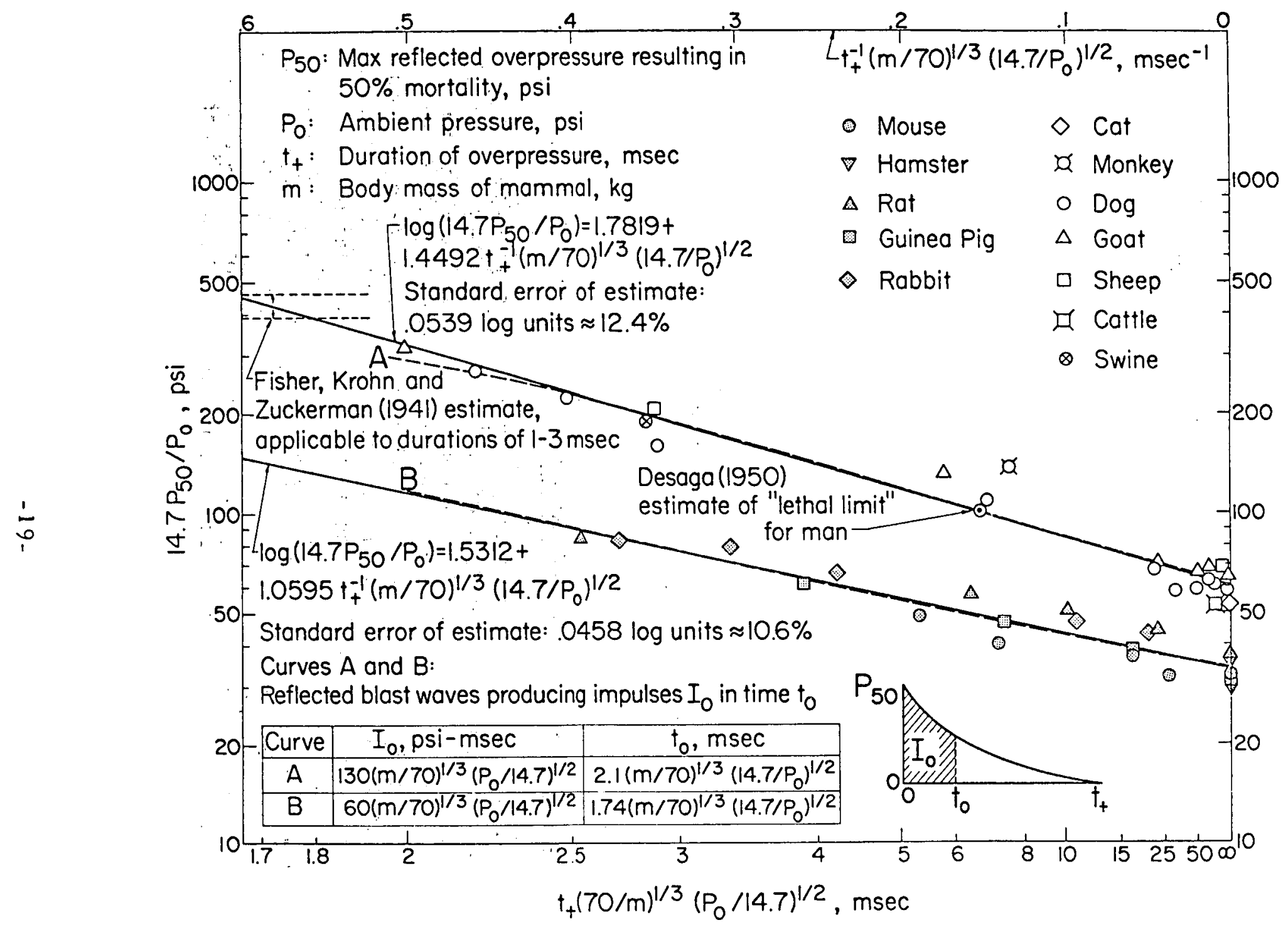

Figure 9. Pressure-duration and partial impulse analyses of animal tolerance data scaled to a body mass of $70-\mathrm{kg}$ and to an ambient pressure of $14.7 \mathrm{psi}$. The experimental data were obtained by exposing animals near a reflecting surface to shock-tube and high-explosive generated blast waves. 
$I_{0}$.

Equation (12) was integrated to time, $t_{0}$, to obtain partial impulse,

$$
I_{0}=P_{m} t_{+} / n^{2}\left[\left\{\exp \left(-n t_{0} / t_{+}\right)\right\}\left(n t_{0} / t_{+}+1-n\right)+n-1\right]
$$

The next step was trial and error in nature and consisted of using Eq. (13) to determine maximum overpressures and durations of blast waves having given values of $t_{O}$ and $I_{O}$ to determine curves similar to $A$ and $B$ in FIGURE 9. In general, the value of $t_{0}$ determines the slope of the curve and the value of $I_{O}$ its vertical displacement. Several trials were made until parameters were found resulting in curves $A$ and $B$ (FIGURE 9) which closely approximate the regression lines for the large and small mammals, respectively.

The characteristic time found using the large animal data is 2.1 msec applicable to the $70-\mathrm{kg}$ mammal and 14.7 -psi ambient pressure (FIGURE 9). This time scaled to a $10-\mathrm{kg}$ mammal and $12-\mathrm{psi}$ ambient pressure is $1.22 \mathrm{msec}$. Referring to the intrathoracic overpressure data plotted in FIGURE 2, the characteristic time of $1.22 \mathrm{msec}$ is approximately the time between arrival of the blast wave at the end-plate and peak intrathoracic overpressure, $1.11 \mathrm{msec}$, and also near the time between arrival of the blast one-half animal width from the endplate and peak intrathoracic overpressure, $1.25 \mathrm{msec}$.

The implication of the above analysis is that the response of the mammal is determined by the magnitude of the impulse occurring within a characteristic time. It should be remembered, however, that the experimental data were obtained with "fast"-rising pressure pulses in a reflecting blast situation and for 50 percent lethality. The characteristic time and partial impulse would probably be different for other levels of response and also for other blast situations, e.g., step loading or free stream.

\section{Estimates of Man's Tole rance to Air Blast}

The experimental data analyzed in the two previous sections and plotted in FIGURE 9 were scaled to an ambient pressure of 14.7 psi and to a body mass of $70 \mathrm{~kg}$ - approximately that of man. A question a rises regarding the applicability of the data in estimating human tolerance to air blast, particularly since two sets of divergent criteria were derived one using the small-animal, and the other the large-animal data. There is no firm assurance than man's response to blast is similar to that of either group; however, two types of evidence are available which indicate that it is probably more similar to that of the large mammals than to that of the small. The first is the physiological data (Crosfill and Widdicombe, 1961) plotted in FIGURE 8 and the second is an estimate of man's tolerance, described below, which was based on human data (Desaga, 1950).

During World War II eight individuals located in an open-topped anti-aircraft gun emplacement were exposed to air blast following the detonation of a 2000-1b bomb. All except one of the exposed men were 
injured, two fatally. The fatal cases were located near a corner where pressure reflection occurred. Desaga estimated the incident overpressure to be $57 \mathrm{psi}$, with reflection to a maximum of $235 \mathrm{psi}$. It is not possible now to say how much time may have elapsed between the occurence of the incident and reflected waves at the location of the fatally injured men. There may well have been a delay of the order of $2 \mathrm{msec}$, a circumstance that could have increased tolerance significantly. It was noted that one of the fatally injured individuals also suffered a fractured skull. Even so, the condition of the lungs described was typical of primary blast injury and no doubt contributed mostly to death which occurred about 45 minutes after exposure in each case.

Making use of these data, Desaga (1950) estimated that the "lethal limit" for man was 100 psi for a charge weight of $550 \mathrm{~kg}$. Data presented elsewhere in the report were used to estimate a pulse duration of 6.6 msec. The point in FIGURE 9 representing these data falls on the tolerance line derived from the data for the large mammals; however, interpretation of "lethal limit" results in 100 psi being the lowest overpressure at which Desaga estimated that lethality would occur - not 50 percent lethality.

It is also instructive to consider previous estimates of man's tole rance to blast which were based on animal data. An early estimate (Fisher etal., 1941) was derived from data obtained with mice, guinea pigs, rabbits, monkeys, and goats. The animals were exposed tail-on to charges detonated at ground level. The goats were restrained with rope netting and the other animals were exposed in wire cages. Extrapolation of the experimental data to $60-$ and $80-\mathrm{kg}$ mammals predicted 50 percent lethal overpressures of 392 and 460 psi, respectively, applicable to pulse durations ranging from 1 to $3 \mathrm{msec}$. The overpressures are plotted in the upper left corner of FIGURE 9 as dotted lines. It was not feasible to extend the lines in the chart to the appropriate duration limits; however, it is apparent that these estimates are in agreement with extrapolated tole rance line derived from the large animal data.

Next to be considered are estimates based on mouse, rat, guinea pig, rabbit, dog, and goat exposures which were similar to those of the present study (Richmond and White, 1962; White et al., 1964; White et al., 1965). Body mass extrapolation of these data to a $70-\mathrm{kg}$ mammal yielded the tolerance data listed in TABLE 2. Agreement between these estimates and those of the present study is good for the "long"-duration waves; however, considerably higher tolerances were predicted for the "short"-duration waves.

Previous estimates of the tolerance of a $70-\mathrm{kg}$ mammal were made by employing the same scaling techniques and the same dog and goat data as those used in the present study (Bowen et al., 1965; White et a1. , 1965). These estimates, listed in TABLE 2, show reasonable agreement with the current estimates derived from data obtained with seven species, the greater deviations occurring for the shorter durations; e.g., 18 percent at $1.73 \mathrm{msec}$, and 10 percent at $2 \mathrm{msec}$. 
TABLE 2. A SUMMARY OF VARIOUS ESTIMATES OF MAN'S TOLERANCE TO AIR BLAST

Tabulated overpressures in psi correspond to 50 percent mortality except where noted. Ambient pressure: 14.7 psi

\begin{tabular}{clccccc}
\hline $\begin{array}{c}\text { Duration } \\
\text { msec }\end{array}$ & $\begin{array}{c}\text { Present } \\
\text { study }\end{array}$ & $\begin{array}{c}\text { Richmond } \\
\text { et al. } \\
\text { 1966b }\end{array}$ & $\begin{array}{c}\text { Bowen } \\
\text { et al. } \\
1965\end{array}$ & $\begin{array}{c}\text { Richmond } \\
\text { \& White, } \\
1962\end{array}$ & $\begin{array}{c}\text { Fisher } \\
\text { et al. } \\
1941\end{array}$ & $\begin{array}{c}\text { Desaga, } \\
1950\end{array}$ \\
\hline $1-3$ & $416 *$ & & $340 *$ & $1000 *$ & $392-469 * * *$ \\
2 & 321 & & 290 & & \\
3 & 184 & $159-220$ & 188 & 528 & \\
5 & 118 & & 120 & 227 & $100 * * *$ \\
6.6 & 100 & & 98 & 168 & \\
10 & 84.5 & & 79 & 120 & \\
20 & 71.5 & & 64 & 87 & \\
30 & 67.6 & & 62 & 78 & \\
60 & 64.0 & & 62 & 71 & \\
400 & 61.0 & 58.3 & 62 & 64 & \\
\hline
\end{tabular}

*Extrapolated to 1.73 msec.

* Lower and higher overpressures apply to $60-$ and $80-\mathrm{kg}$ mammals, respectively.

***"Lethal limit" overpressure defined as lowest overpressure at which mortality occurs. 
The other estimates to be considered were made with essentially the same data as those used in the present study (Richmond et al., $1966 \mathrm{~b})$. Using tolerance data for nine species of mammals varying in size from the mouse to the swine, body mass extrapolation yielded predictions of 50 percent lethal overpressures for man ranging between 130 and 180 psi for wave durations of $3 \mathrm{msec}$ and an ambient pressure of $12 \mathrm{psi}$. These overpressures scaled to 14.7-psi ambient pressure, 159-220 psi, bracket the estimate of the present study, 184 psi. By similar methods, an estimate of 47.6 psi was obtained for man exposed to "long"-duration waves. This overpressure scaled to $14.7 \mathrm{psi}$ ambient pressure, 58.3 psi, agrees well with the current estimate listed in TABLE 2 for a duration of $400 \mathrm{msec}, 61.0 \mathrm{psi}$.

\section{Non-penetrating Missile Experiments}

The experimental arrangement for the non-penetrating missile studies is illustrated in FIGURE 10. The air gun used in these experiments has been described previously (Bowen et al., 1956). Note the light beams and photocells placed one foot apart near the end of the barrel. An electronic timer was started and stopped by the missile interrupting the first and second light beams, respectively. The elapsed time was used to determine the impact velocity of the missile.

A cup-shaped missile was constructed of aluminum in such a way that its mass could be varied. Impact occurred on the flat circular end whose diameter was $7 \mathrm{~cm}$. The least massive missile used was a cylindrical piece of balsa wood with an aluminum plate cemented to the end impacting the dog.

A grid placed below the missile trajectory served as a background for pictures taken by a high-speed motion picture camera (Fastex) located about eignt feet directly above the end of the barrel.

The pendulum-like mount for the dog had a radius of motion of about $10 \mathrm{ft}$. The underside of the dog was supported by a shallow channel about four inches wide which was contoured to fit the neck and head. The experimental animals were anesthetized and positioned so that impact would occur with the rib cage near the mid-lateral point of the right side of the thorax.

\section{Missile Time-Displacement Study}

Motion picture records made in the experiments described above were used to determine the positions of the missile on successive frames taken at the rate of $6-12$ per msec. Readings were made just prior to impact to determine impact velocity and for several msec afterwards.

Velocity and acceleration of the missile as a function of time were determined by a moving spline method (Jordan, 1965) assuming accele ration to be constant over each time interval $(.08-.17 \mathrm{msec})$ and 


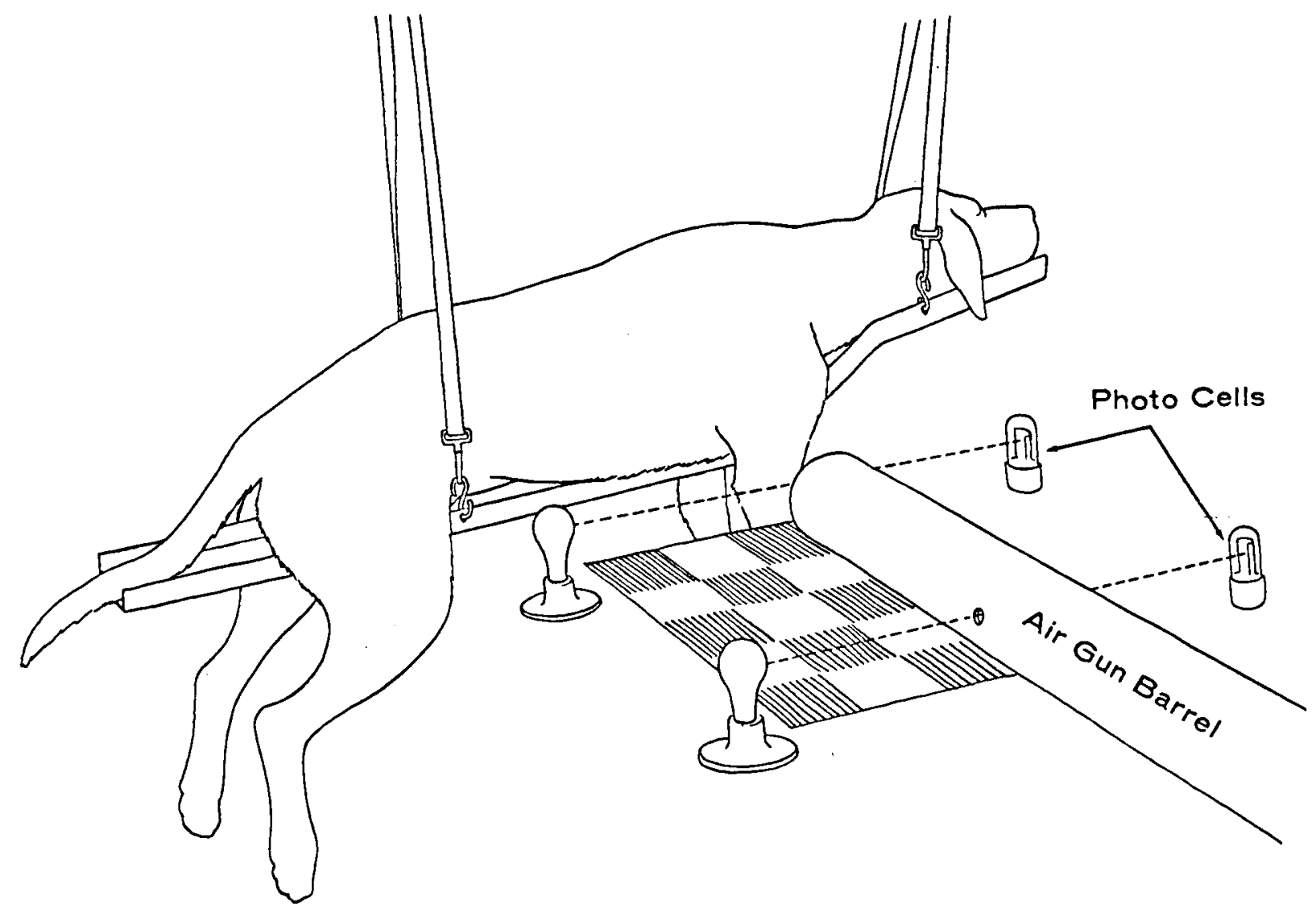

Figure 10. Experimental arrangement for the non-penetrating missile studies. 
velocity to vary linearly with time in the same interval. A second degree polynominal was fitted by least squares to the first three displacement points, forcing the curve to pass through the initial point with a predetermined initial slope (velocity). The first and second derivatives of the fitted polynominal were used to compute velocity at the end of the first time step and the average acceleration during the first interval. Moving forward one time interval, the procedure was repeated making use of the previously computed displacement and velocity to force the initial displacement and slope of the new fit. This was continued until all the displacement data had been analyzed. This method, while producing some smoothing of the raw data, did not obscure significant features of the time-displacement curve as did other methods which were tried.

The plotted points in FIGURES 11 and 12 illustrate graphically the results of two time-displacement analyses. Note in each case that the missile velocity decreased rapidly for about $0.4 \mathrm{msec}$ corresponding to the time necessary for a section of the chest wall to attain the same velocity as the missile. The next marked decrease in missile velocity occurred from about .7 to $1.2 \mathrm{msec}$, evidently corresponding to the buildup of gaseous pressure in the right lung due to the inward motion of a portion of the right chest wall.

The experiments described above were simulated with the model using, except where noted, the model parameters listed in TABLE 1 scaled to the appropriate body mass. Two model solutions are shown in FIGURE 11 for experiment M50. The first was made with the nominal value of lung volume for a $17.7-\mathrm{kg} \mathrm{dog}\left(457 \mathrm{~cm}^{3}\right)$ and resulted in appreciable deviation, after one msec, of the computed displacements from the measured ones. The second solution was obtained with a lung volume 75 percent of its nominal value. In this instance, the computed displacement curve agrees well with the measured points. The method used to support the anesthetized dogs illustrated in FIGURE 10 may have caused part of the abdominal contents to move into the chest cavity, reducing the lung volume. Although information directly applicable to this situation could not be obtained, Lim and Luft (1959) measured functional residual capacities of human subjects in the supine position that were $65-70$ percent of those measured when the subjects were standing erect.

As mentioned above, the displacements computed with a reduced lung volume are reasonably consistent with the measured points (FIGURE 11). The computed velocity and deceleration curves agree reasonably well at the beginning and the end of the two-msec time interval, but deviate somewhat from the experimental points in the middle of the interval.

Intrathoracic overpressures computed for the same experiment (M50) are plotted in FIGURE 13 for both values of lung volume. Since impact occurs on the right side of the thorax, pressure builds up in the right lung first and later is transmitted to the left lung through motion of the tissue between the lungs, simulated in the model by the 


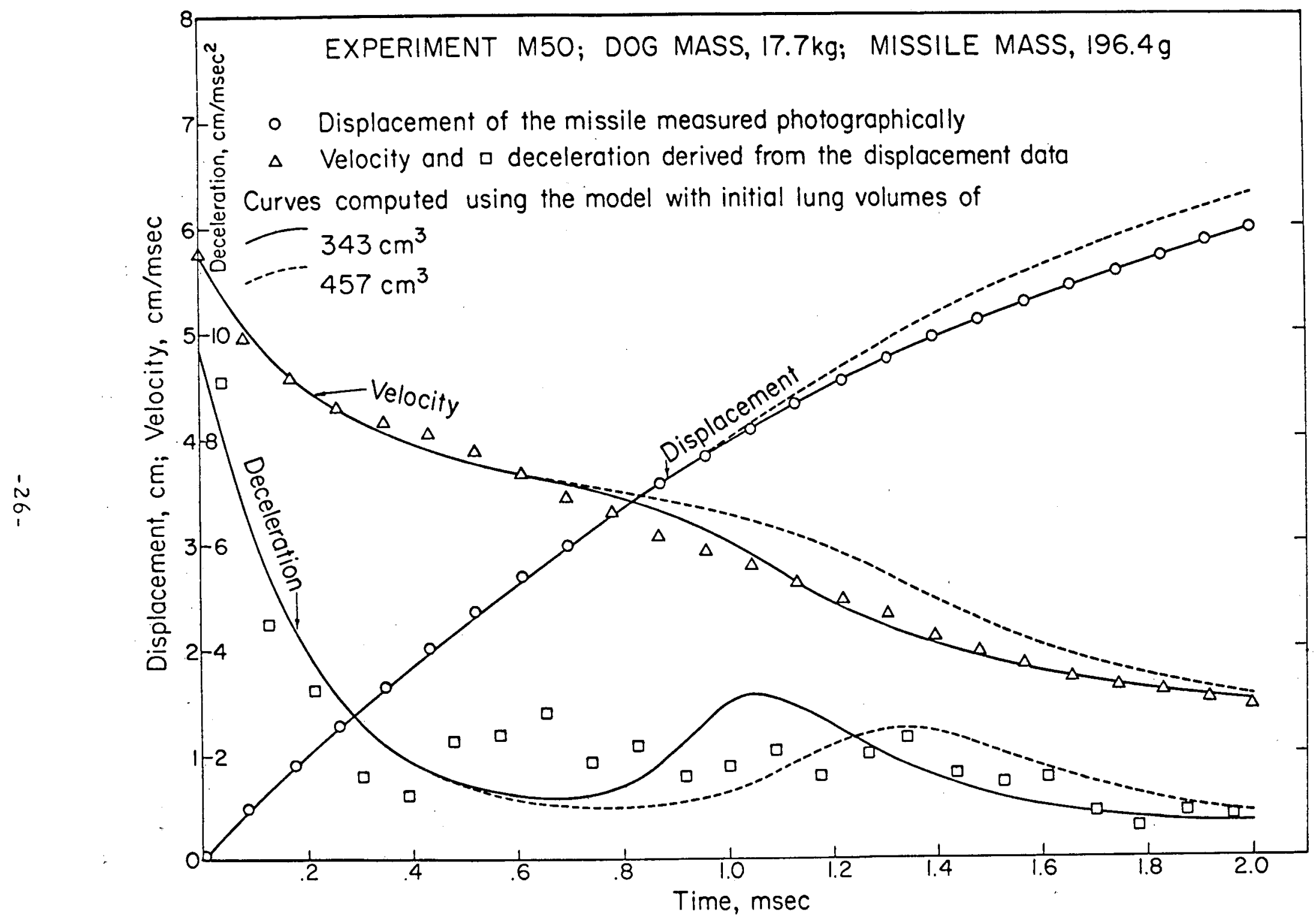

Figure 11. A comparison of computed and measured displacement parameters for non-penetrating missile experiment M50. 


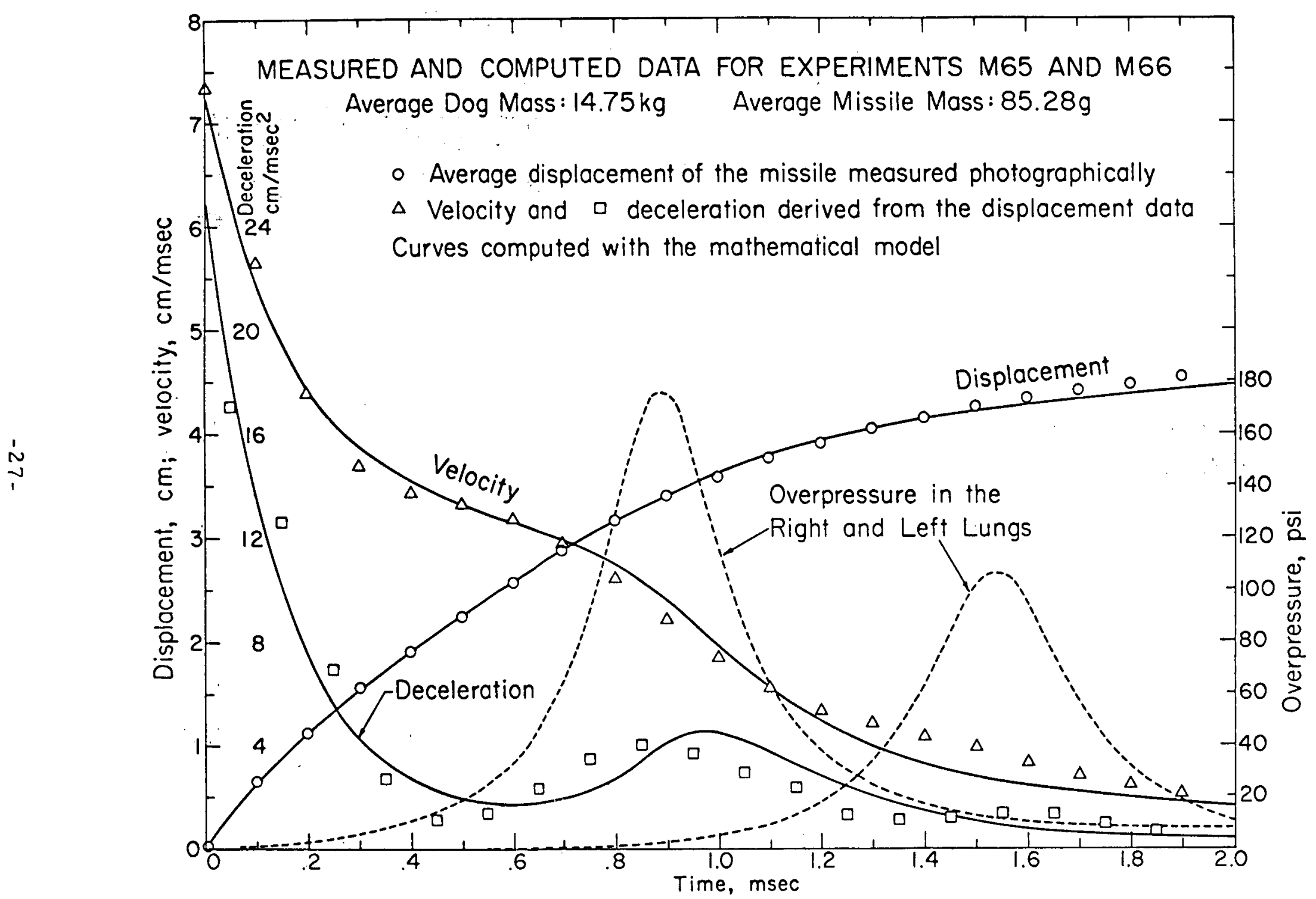

Figure 12. A comparison of computed and measured displacement parameters for non-penetrating missile experiments M65 and M66. 


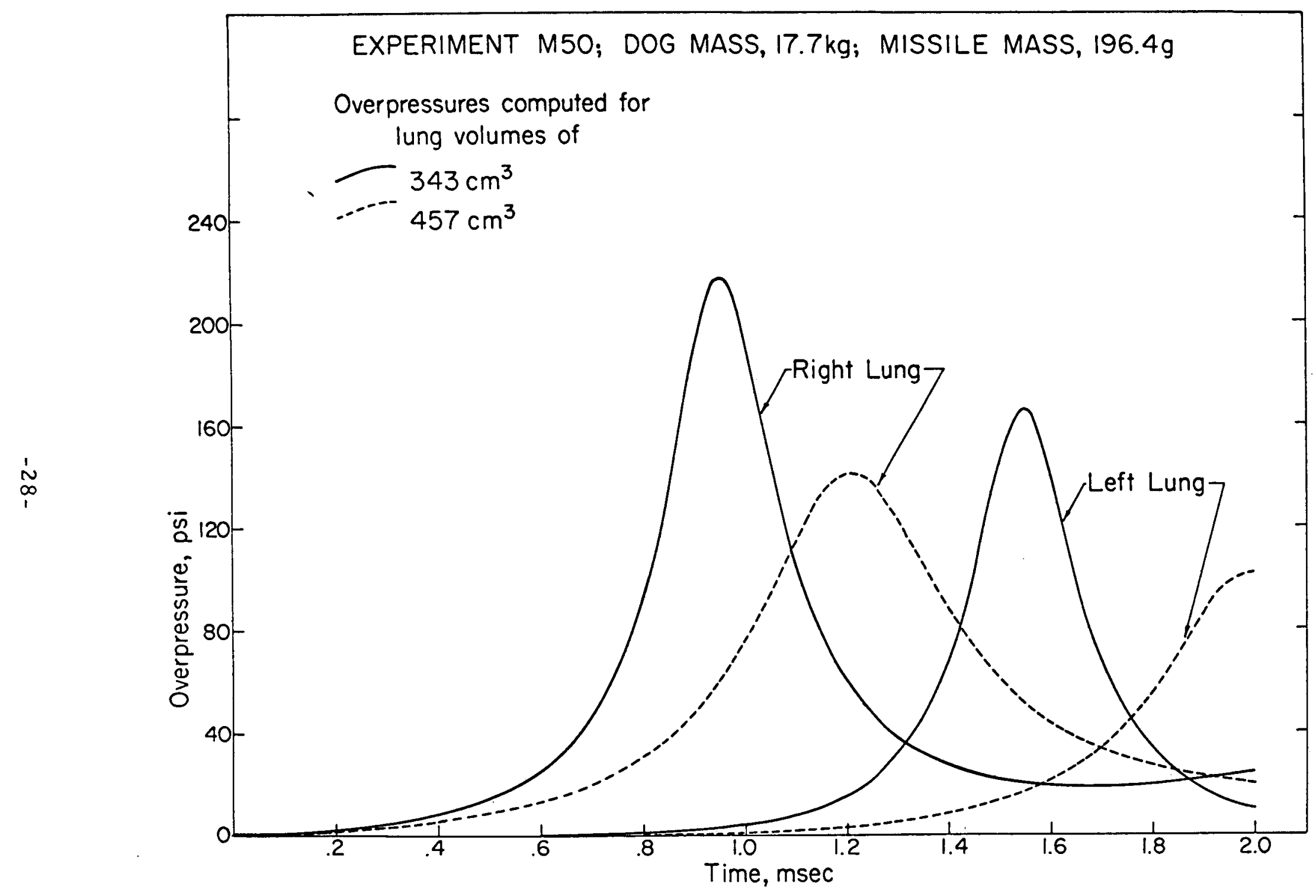

Figure 13. Computed intrathoracic overpressures for non-penetrating missile experiment M50. 
middle piston. Note the significant difference in magnitude and time of the peak intrathoracic overpressures depending on the lung volume used in the model. For the right lung, the peak pressure occurs just prior to a peak in the computed missile deceleration curve.

Similar experimental and theoretical data are plotted in FIGURE 12 for experiments M65 and M66. The displacement data for these experiments were averaged since the impact velocities were the same and the dog and missile masses were nearly the same. The lung volume used in the model to simulate these experiments was $305 \mathrm{~cm}^{3}, 80$ percent of the nominal value. A detectable deviation of the computed displacement curve from the experimental points occurs after $1.5 \mathrm{msec}$. The computed velocity and displacement curves, however, agree reasonably well in the salient features with the experimentally determined points. As noted in the data shown in FIGURES 11 and 13, the second peak in the missile deceleration curve is associated with the peak overpressure in the right lung.

Analysis of Non-penetrating Missile Data

Results obtained in 45 non-penetrating missile experiments, previously described, are presented in TABLE 3. Among other things, the ribs fractured in each experiment are identified by number. These data indicate some variation in the location of the impact although the aiming point was always the mid-lateral region of the right side of the thorax.

The ratio of lung mass to body mass was used as an objective index of animal response. Data listed in TABLE 3 were used to plot the percent left lung mass of body mass, LL, as a function of the corresponding normalized mass of the right lung, $R L$, as illustrated in FIGURE 14. The dashed line in this figure labeled "equal fractional increase in lung masses" was determined from reported relative masses of the right and left lungs of adult dogs (Schilling, 1965). If the lungs of the experimental animals had increased in mass in proportion to the original masses, the experimental points would fall along this line. However, the plotted data indicate that the response of the right lungs was always greater than that of the left as could be expected since impact always occurred on the right chest wall. The left lung response, LL, remains small until the value of RL exceeds one percent. From this point, the values of LL generally increase but at a slower rate than $R L$. Thus, the transition point where $\mathrm{RL} \approx 1 \%$ indicates the beginning of significant bilateral damage. In addition to impact per se the incidence of rib fracture, which sometimes occurred even at low response levels, probably also served to increase the mass of the right lung relative to that of the left.

The sums of the left and right lung masses were used in making a general analysis of the animal response data; viz., $L=L L+R L=$ the mass of both lungs divided by body mass and expressed as a percentage. FIGURE 15 contains a plot of impact velocity, vo, versus missile mass as a percent of dog mass, $M$, plotted on a reciprocal scale, with measured 
TABLE 3. DATA FROM NON-PENETRATING MISSILE EXPERIMENTS

\begin{tabular}{|c|c|c|c|c|c|c|c|}
\hline Code & $\begin{array}{c}\text { Dog } \\
\text { Mass } \\
\text { kg }\end{array}$ & $\begin{array}{c}\text { Missile } \\
\text { Mass } \\
\text { g }\end{array}$ & $\begin{array}{l}\text { Impact } \\
\text { Velocity } \\
\mathrm{cm} / \mathrm{msec} \text {. }\end{array}$ & $\begin{array}{c}\text { Mass of } \\
\text { Right } \\
\text { Lung } \\
g\end{array}$ & $\begin{array}{l}\text { Mass of } \\
\text { Left } \\
\text { Lung } \\
\text { g. }\end{array}$ & $\begin{array}{c}\text { Ribs } \\
\text { Fractured } \\
\text { (rib no.) }\end{array}$ & $\begin{array}{c}\text { Time } \\
\text { to Death, } \\
\text { min. * }\end{array}$ \\
\hline M.27 & 15.6 & 196.3 & 4. 74 & 92 & 52 & 0 & s \\
\hline M 28 & 14.5 & 196.3 & 6.07 & 272 & 106 & 4,$7 ; 8$ & $1-2$ \\
\hline M 29 & 20.4 & 196.3 & 5.49 & 289 & 122 & 7,8 & $\mathrm{~s}$ \\
\hline M 30 & 13.6 & 196.3 & 5.67 & 300 & 107 & 4 & 15 \\
\hline M 31 & 21.5 & 196.3 & 3.90 & 159 & 75 & 0 & $\mathbf{s}$ \\
\hline M 32 & 18.8 & 196.3 & 3.05 & 89 & 53 & 0 & $s$ \\
\hline M 33 & 23.1 & 381.0 & 4.48 & 184 & 81 & $4,5,6,7$ & $s$ \\
\hline M 34 & 20.9 & 381.0 & 4.69 & 307 & 140 & 4 & s \\
\hline M 35 & 12.2 & 381.0 & 4. 72 & 210 & 89 & 5,6 & 6 \\
\hline M 36 & 22.0 & 196.3 & 4.12 & 282 & 78 & 0 & 30 \\
\hline M 38 & 16.8 & 98.0 & 5.09 & 125 & 71 & 5 & $\mathbf{s}$ \\
\hline M 39 & 18.1 & 381.0 & 2.25 & 126 & 68 & 0 & $\mathbf{s}$ \\
\hline M 40 & 15.4 & 381.0 & 2.23 & 131 & 58 & 0 & $\mathbf{s}$ \\
\hline M 41 & 18.1 & 381.0 & 1.89 & 120 & 81 & $7_{x \in *}$ & $\mathbf{s}$ \\
\hline M 43 & 16.3 & 381.0 & 3.57 & 227 & 98 & $4^{3+2 x}$ & $\mathbf{s}$ \\
\hline M 44 & 14.7 & 381.0 & 3.81 & 226 & 85 & 4 & $\mathbf{s}$ \\
\hline M 45 & 17.0 & 196.4 & 6.19 & 292 & 132 & 4,5 & $\mathbf{s}$ \\
\hline M 46 & 16.3 & 196.4 & 3.08 & 110 & 75 & 0 & $\mathbf{s}$ \\
\hline M 47 & 18.1 & 196.4 & 3.54 & 166 & 77 & 0 & $\mathbf{s}$ \\
\hline M 48 & 18.1 & 196.4 & 6.07 & 329 & 121 & 4,6 & $8-10$ \\
\hline M 49 & 16.3 & 196.4 & 5.21 & 197 & .62 & 0 & $15-17$ \\
\hline M 50 & 17.7 & 196.4 & 5.76 & 352 & 148 & 5,6 & $\mathbf{s}$ \\
\hline M 51 & 18.8 & 196.4 & 6.31 & 282 & 106 & 6,7 & 40 \\
\hline M 52 & 16.8 & 196.4 & 6.07 & 169 & 50 & 7,8 & $35-40$ \\
\hline M 53 & 17.7 & 196.4 & 6.04 & 251 & 74 & 5 & $\mathbf{s}$ \\
\hline M 54 & 18.1 & 196.4 & 5.91 & 347 & 109 & 4 & 26 \\
\hline M 55 & 17.5 & 196.4 & 3.50 & 125 & 69 & 0 & $\mathbf{s}$ \\
\hline M 56 & 16.6 & 196.4 & 3.60 & 201 & 70 & 7 & $\mathbf{s}$ \\
\hline M 57 & 14.7 & 196.4 & 3.14 & 146 & 58 & 0 & $\mathbf{s}$ \\
\hline M 58 & 15.4 & 196.4 & 2. 31 & 76 & 53 & 0 & $\mathbf{s}$ \\
\hline M 59 & 15.4 & 196.4 & 2.62 & 76 & 49 & 0 & $\mathbf{s}$ \\
\hline M 60 & 16.8 & 196.4 & 3.85 & 138 & 69 & 0 & $\mathbf{s}$ \\
\hline M 61 & 16.8 & 196.4 & 4.69 & 244 & 68 & 5 & $\mathbf{s}$ \\
\hline M 62 & 17.7 & 382.8 & 2.65 & 107 & 59 & 5 & $\mathbf{s}$ \\
\hline M 63 & 18.6 & 382.8 & 3.17 & 237 & 97 & 8 & $\mathbf{s}$ \\
\hline M 64 & 18.1 & 382.8 & 4.66 & 210 & 84 & $6,7,8$ & 14 \\
\hline M 65 & 15.0 & 85.8 & 7.35 & 168 & 60 & 0 & 4 \\
\hline M 66 & 14.5 & 85.3 & 7.35 & 195 & 62 & 0 & $\mathbf{s}$ \\
\hline M 67 & 18.1 & 63.0 & 7.22 & 115 & 67 & 0 & $\mathbf{s}$ \\
\hline M 68 & 14.5 & 63.3 & 9.14 & 168 & 74 & 4 & $s$ \\
\hline M 69 & 20.9 & 86.0 & 6.04 & 193 & 75 & 4,5 & $\mathbf{s}$ \\
\hline M 70 & 22.2 & 86.0 & 6.22 & 253 & 127 & 0 & $\mathbf{s}$ \\
\hline M 71 & 21.5 & 85.6 & 5.61 & 151 & 77 & 0 & s \\
\hline M 72 & 19.1 & 85.6 & 8.02 & 245 & 96 & 4 & $\mathbf{s}$ \\
\hline M 73 & 20.2 & 85.6 & 8.66 & 254 & 133 & 9 & s \\
\hline
\end{tabular}

* $s$ indicates sacrifice in $30-40 \mathrm{~min}$.

* dislocated from vertebra 


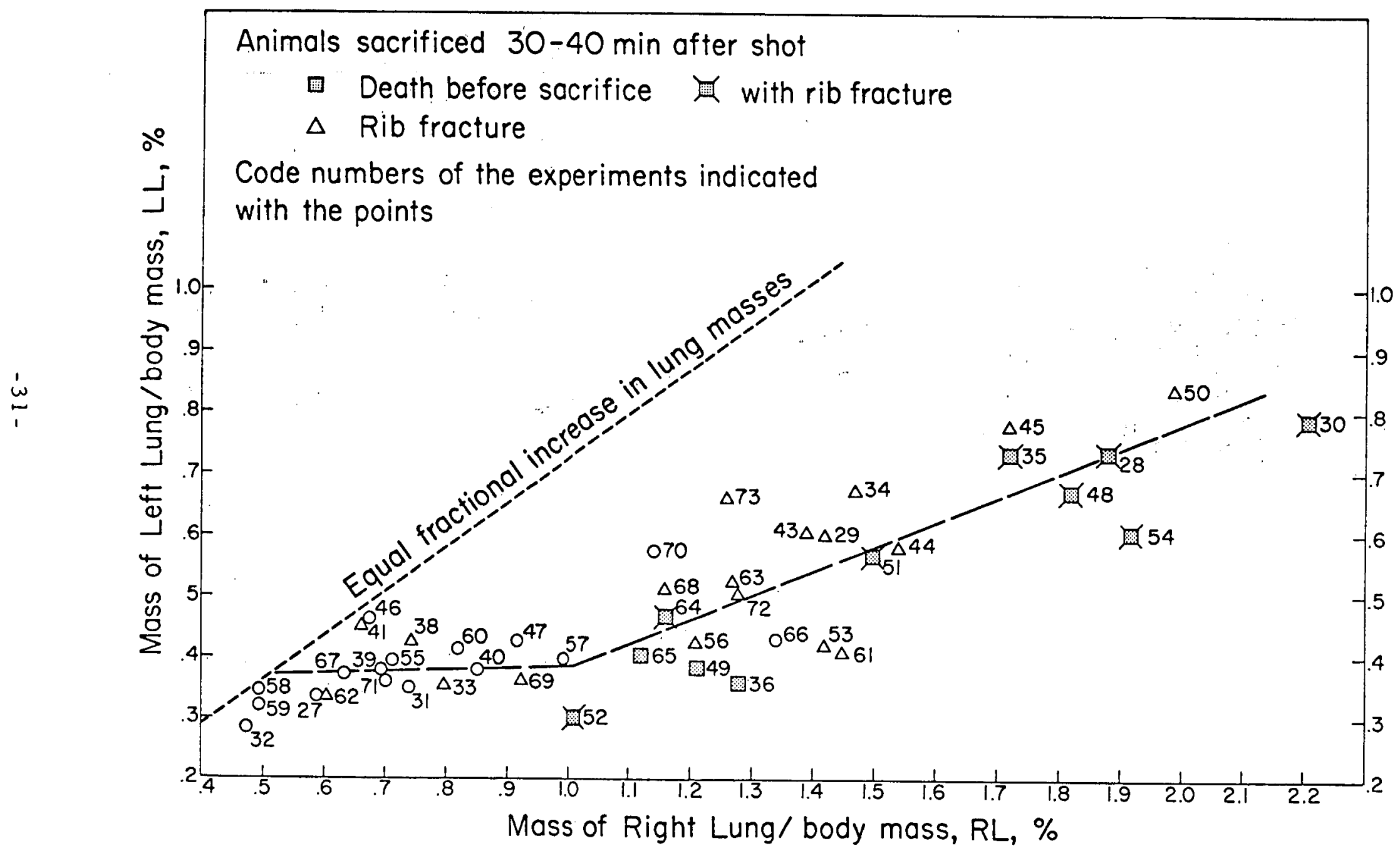

Figure 14. A comparison of the masses of the right and left lungs of dogs used in the non-penetrating missile experiments. See TABLE.l. 


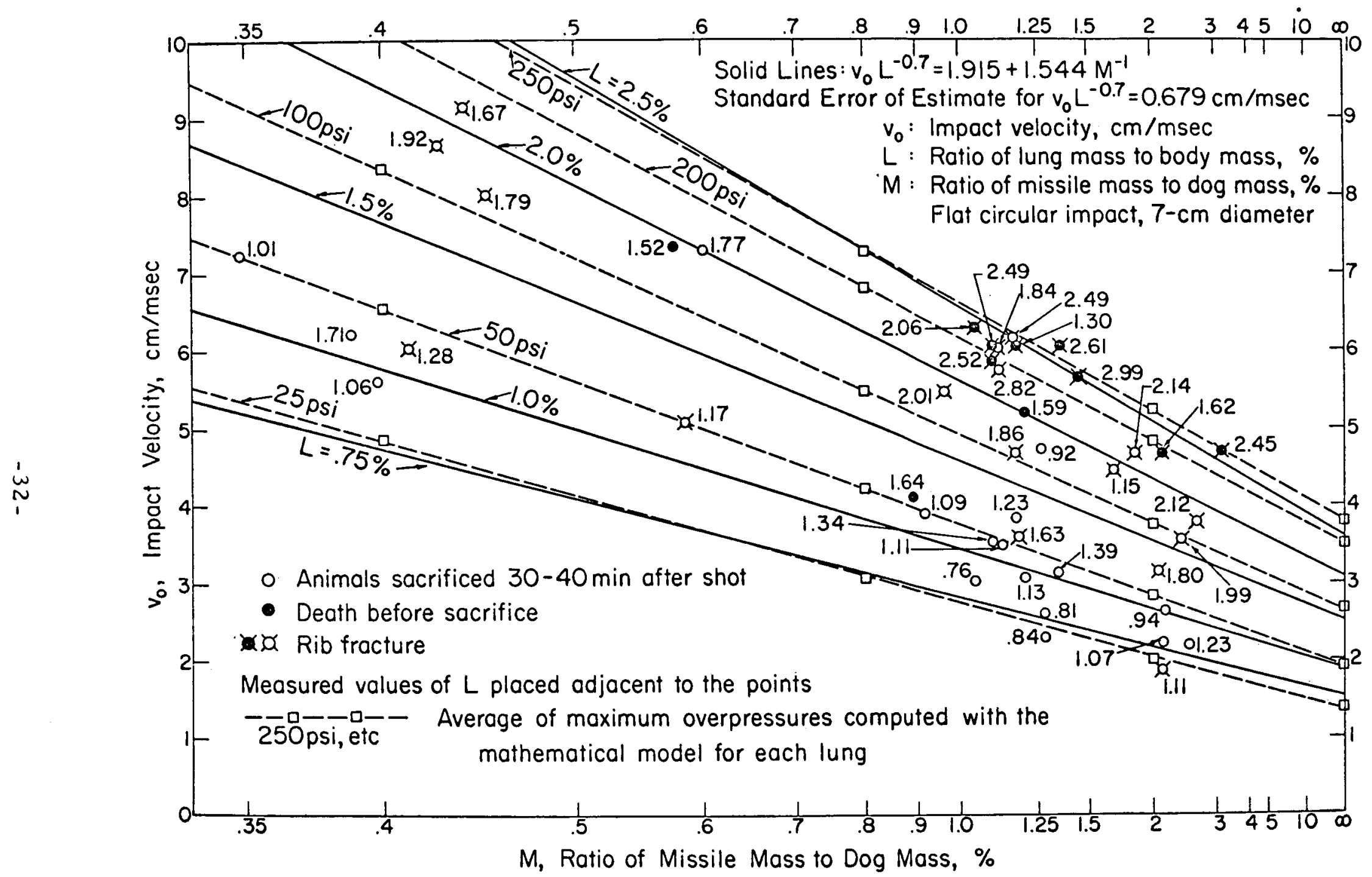

Figure 15. Results of a general analysis of the non-penetrating missile experiments, The lines of constant peak intrathoracic overpressure were computed with the model. 
values of $L$ placed adjacent to each point.* An equation of the following form was found to fit the experimental points:

$$
v_{0} L^{-a}=b+c M^{-1}
$$

where $a, b$, and $c$ are constants to be determined from the experimental data. Least squares regression analyses were made to evaluate $b$ and $c$ for several assumed values of $a$. The value of a which produced the lowest standard error of estimate was 0.7 and the corresponding values of $b$ and $c$ were 1.915 and 1.544 , respectively.

Equation (14) is plotted in FIGURE 15 for five values of $L$ spanning the range of the experimental data. It is of interest that the impact velocity for a given $L$ response approaches a constant value as the missile mass approaches infinity. This, of course, could not be true if the animals had been securely held in a fixed position.

The mathematical model was used to simulate the non-penetrating missile experiments using as an index of animal response the average of the maximum overpressures computed for each lung. Values of the model parameters listed in TABLE 1 for a $10-\mathrm{kg}$ dog were used in this study with the exception of those for lung volumes which were assumed to be 80 percent of their nominal values. (See discussion in the last section.)

The computed iso-overpressure lines plotted in FIGURE 15 are approximately parallel to the iso-response lines determined from the experimental data. However, as was shown by the data plotted in FIGURE 13, the magnitude of the computed overpressures for a given experimental situation is dependent to a great degree upon the assumed value of the lung volume.

While direct correspondence cannot be justified, it is of interest to note that the 250-, 200-, and 100-psi iso-overpressure lines shown in FIGURE 15 would be expected to produce approximately 50,25 , and 0 percent mortality, respectively, according to the data presented in FIGURE 3 (right). It appears that the animal mortalities shown in FIGURE 15 are somewhat higher than the above figures although insufficient data are available for a rigorous lethality analysis.

\section{Summary}

A mathematical model was devised to study the principal biophysical mechanisms of the thorax subjected to air blast or to non-penetrating missile impact with a chest wall. The salient features of the model were described and results were presented of a dimensional analysis of the model parameters. The dimensional analysis, based on similarity of

* Note that the scaling relationship expressed in Eq. (11) could not be satisfied since the impact areas were the same for all the experiments but the body masses were not. 
mammalian species, resulted in scaling equations relating for a given biological response the parameters of similar blast waves (e.g., maximum overpressure and duration of the wave) to the body mass of similar mammals and to the ambient pressure. The scaling relations were interpreted for high-explosive blast waves making use of the usual scaling equations for explosives. Also, the analysis was extended to include nonpenetrating missile impact with the chest - relating the mass and impact area of the missile to body mass, and the impact velocity to ambient pressure.

Estimated parameters were used in the model to simulate a blast experiment in which a dog was placed at the end-plate of a shock tube. Computed intrathoracic overpressures showed reasonable agreement with those measured.

A sensitivity study indicated that computed. lung pressures decrease with increases in the magnitudes of the damping factors, lung volumes, orifice areas, and spring constants (listed in the order of importance). Increases in the masses and areas of the pistons representing the chest walls, however, result in higher computed lung pressures. These results were compared to intrathoracic pressures computed for various blast waves producing different levels of mortality.

Intrathoracic pressures were computed for dogs exposed broadside to "long" - and "short"-duration blast waves. Experimental results for guinea pigs were used to help evaluate the results obtained for the "long"duration wave.

Experimental data were used to show that approximately equivalent mortality responses were obtained for mice, rats, guinea pigs, and rabbits exposed to step loads of constant magnitude if the time between the incident and reflected shocks were proportional to the cube root of body mass.

High-explosive data were used to establish for 50 percent mortality the relationship between (height of burst/(body mass) $1 / 3$ and (mass of explosive charge)/(body mass). It was found that two relationships exist, one for small animals (mice, rats, guinea pigs, and rabbits) and a nother for larger animals (monkeys, dogs, goats, sheep, and swine). Possible differences in the two groups of species were discussed in terms of published physiological data.

A general analysis was presented of pressure-duration data obtained by exposing experimental animals against reflecting surfaces to blast waves generated by high explosives and shock tubes. The analysis showed approximately similar responses within each of two groups of species: (1) mouse, hamster, rat, guinea pig, and rabbit; (2) cat, monkey, dog, goat, sheep, cattle, and swine. An equation was derived for each group giving 50 percent lethal overpressure as a function of wave duration, ambient pressure, and body mass of the mammal. 
Further analyses showed that the blast waves producing 50 percent mortality have two approximately invarient parameters for a given body mass and ambient pressure; viz., partial impulse occurring within a characteristic time. These parameters were evaluated for each of the groups previously mentioned and the appropriate scaling functions indicated. The characteristic time was related to the time during which the most significant animal response occurs - maximum compression of the thorax.

Using appropriate scaling procedures, the analyses mentioned above were made applicable to $70-\mathrm{kg}$ mammals and 14.7-psi ambient pressure. The resulting blast tolerances were compared to those previously estimated for man.

Experiments were described in which the rib cage of dogs were struck by non-penetrating missiles near the mid-lateral point of the thorax. Photographic data were used to make time-displacement analyses for the missile. The results were compared with those computed with the model and various biophysical mechanisms were discussed.

Results obtained from 45 non-penetrating missile experiments were presented in tabular form. Lung mass data were plotted to show that the lung on the side receiving the impact showed the greatest response to the impact but that significant bilateral response occurred for the more damaging impacts.

A general analysis of the non-penetrating missile data resulted in an equation describing the empirical relationship between (1) lung mass normalized to body mass, (2) impact velocity of the missile, and (3) missile mass normalized to body mass. It was found that peak intrathoracic pressures computed with the model were approximately constant for the experimental conditions producing constant normalized lung masses. 


\section{REFERENCES}

Bowen, I. G., A. F. Strehler and M. B. Wetherbe, "Distribution and Density of Missiles from Nuclear Explosions, "USAEC Civil Effects Test Group Report, WT-1168, Office of Technical Services, Department of Commerce, Washington, D. C., December 14, 1956.

Bowen, I. G., A. Holladay, E. R. Fletcher, D. R. Richmond and C. S. White, "A Fluid-Mechanical Model of the Thoraco-Abdominal System with Application to Blast Biology, "Technical Progress Report, DASA-1675, Defense Atomic Support Agency, Department of Defense, Washington, D. C., June 14, 1965.

Brode, H. L., "A Calculation of the Blast Wave from a Spherical Charge of TNT, "Research Memorandum-RM-1965, The RAND Corporation, Santa Monica, California, 1957.

Clemedson, C. -J. and A. Jönsson, "Transmission of Elastic Disturbances Caused by Air Shock Waves in a Living Body, "J. Appl. Physiol., 16: 426-430, 1961.

Clemedson, C. -J. and A. Jönsson, "Dynamic Response of Chest Wall and Lung Injuries in Rabbits Exposed to Air Shock Waves of Short Duration," Acta Physiol. Scand., 62 (Suppl. 233): 3-31, 1964.

Crosfill, M. L. and J. G. Widdicombe, "Physical Characteristics of the Chest and Lungs and the Work of Breathing in Different Mammalian Species, "J. Physiol. (London), 158: 1-4, 1961 .

Damon, E. G., D. R. Richmond and C. S. White, "The Effects of Ambient Pressure on the Tolerance of Mice to Air Blast, "Technical Progress Report, DASA-1483, Defense Atomic Support Agency, Department of Defense, Washington, D. C., March 1964. Subsequently published in Aerospace Med., 37: 341-347, 1966.

Damon, E. G., C. S. Gaylord, W. Hicks, J. T. Yelverton, D. R. Richmond and C. S. White, "The Effects of Ambient Pressure on Tolerance of Mammals to Air Blast, "Technical Progress Report, DASA-1852, Defense Atomic Support Agency, Department of Defense, Washington, D. C., August 1966 (in press).

Damon, E. G., C. S. Gaylord, J. T. Yelverton and D. R. Richmond, "The Tolerance of Cattle to 'Long'-Duration Reflected Pressures in a Shock Tube," Technical Progress Report, DASA-1855, Defense Atomic Support Agency, Department of Defense, Washington, D. C. ; August 1966 (in press). 
Desaga, H., "Blast Injuries," Chap. 14-D, German Aviation Medicine, World War II, Vol. 2, pp. 1274-1293, U. S. Government Printing Office, Washington, D. C., 1950.

Fisher, R. B., P. L. Krohn and S. Zuckerman, "The Relationship between Body Size and the Lethal Effects of Blast, "Ministry of Home Security Report R. C. 284, Oxford University, Oxford, England, December 10, 1941 .

Goodman, H. J., "Compiled Free-Air Blast Data on Bare Spherical Pentolite, "Ballistic Research Report 1092, Aberdeen Proving Ground, Maryland, 1960.

Iwanski, E. C., T. H. Schiffman and T. A. Zaker, "Blast Effects on Buildings and Structures, Operation of 6-Foot and 2-Foot Shock Tubes. High Pressure Tests on Simple Shapes, "Final Report No. 10, Armour Research Foundation, Chicago, 1957.

Jordan, T. L., "Smoothing and Multivariable Interpolation with Splines," LA-3137, Los Alamos Scientific Laboratory, Los Alamos, New Mexico, 1965.

Lim, T. P. K. and U. C. Luft, "Alteration in Lung Compliance and Functional Residual Capacity with Posture," J. Appl. Physiol. , 14: $164-166,1959$.

Rashevsky, N., Mathematical Biophysics; Physico-Mathematical Foundations of Biology, Third Revised Edition, Vol. 2, Dover Publications, Inc., New York, 1959.

Richmond, D. R. and Staff, Lovelace Foundation for Medical Education and Research, Albuquerque, New Mexico, Unpublished Data.

Richmond, D. R., E. G. Damon, I. G. Bowen, E. R. Fletcher and C. S. White, "Air-Blast Studies with Eight Species of Mammals," Technical Progress Report, DASA-1854, Defense Atomic Support Agency, Department of Defense, Washington, D. C. , August 1966 (in press).

Richmond, D. R., R. V. Taborelli, F. Sherping, M. B. Wetherbe, R. T. Sanchez, V. C. Goldizen and C. S. White, "Shock Tube Studies of the Effect of Sharp-Rising, Long-Duration Overpressures on Biological Systems, "USAEC Technical Report, TID-6056, Office of Technical Services, Department of Commerce, Washington, D. C., March 10, 1959.

Richmond, D. R. and C. S. White, "A Tentative Estimation of Man's Tolerance to Overpressures from Air Blast, "Proceedings of the Symposium on Effectiveness Analysis Techniques for Non-Nuclear Warheads against Surface Targets, October 30-31, 1962, Vol. 1, pp. L - L-34, U. S. Naval Weapons Laboratory, Dahlgren, Virginia. Subsequently published as Technical Progress Report, DASA-1335, Defense Atomic Support Agency, Department of Defense, Washington, D. C., November 7, 1962. 
Richmond, D. R. and C. S. White, "Biological Effects of Blast and Shock, "Technical Progress Report, DASA-1777, Defense Atomic Support Agency, Department of Defense, Washington, D. C., April 1966.

Schardin, H., "The Physical Principles of the Effects of a Detonation," Chap. 14-A, German Aviation Medicine, World War II, Vol. 2, pp. 12071224, U. S. Government Printing Office, Washington, D. C., 1950.

Schilling, J. A., "Pulmonary Resection and Sequelae of Thoracic Surgery, "Handbook of Physiology, Section 3: Respiration, pp. 1531-1552, American Physiology Society, Washington, D. C., 1965.

von Gierke, H. E., "Biodynamic Response of the Human Body," Applied Mechanics Reviews, 17: 951-958, 1964.

White, C. S., I. G. Bowen and D. R. Richmond, "A Comparative Analysis of Some of the Immediate Environmental Effects at Hiroshima and Nagasaki," Health Physics, 10:89-150, 1964. Subsequently published as USAEC Civil Effects Test Operations Report, CEX-63.7, Office of Technical Services, Department of Commerce, Washington, D. C., August 1964.

White, C. S., I. G. Bowen and D. R. Richmond, "Biological Tole rance to Air Blast and Related Biomedical Criteria, "USAEC Civil Effects Test Operations Report, CEX-65.4, Office of Technical Services, Department of Commerce, Washington, D. C., October 18, 1965. 


\section{APPENDIX}

Evaluation of Model Parameters for the Dog

The average lung volume defined in FIGURE 8 was obtained from data reported for dogs (Crosfill and Widdicombe, 1961). Assuming that the volume ratio of the two lungs is the same as the measured mass ratio for dogs (Schilling, 1965), 58 percent of the total lung volume was apportioned to the right lung and 42 percent to the left. These and other model parameters scaled to a $10-\mathrm{kg}$ dog are listed in TABLE 1, the subscript 1.referring to the right lung and 2 to the left. The symbols used to identify the parameters are defined in FIGURE 1 .

Spring constants, $K_{1}$ and $K_{2}$, and orifice areas, $A_{1}^{\prime}$ and $A_{2}^{\prime}$, were evaluated by methods already described (Bowen et al., 1965). The value of the spring constant applicable to missile impact, $K_{4}$, was obtained by static tests in which force was measured as a function of displacement of the chest of a dog, the area of contact with the chest wall being the same as that of the missile. The effective mass, $M_{3}$, of the middle piston representing the tissue between the two lungs was assumed to be that reported for the heart (Rashevsky, 1959).

The initial slopes of measured missile velocity curves, $(d v / d t)_{0}$, were used to estimate the value of the damping factor, J4, as follows:

$$
\mathrm{J}_{4}=-\left(\mathrm{M}_{4} / \mathrm{v}_{\mathrm{o}}\right)(\mathrm{dv} / \mathrm{dt})_{0}
$$

where $\mathrm{M}_{4}$ is the mass of the missile and $v_{0}$ is impact velocity. The value of $\mathrm{J}_{4}$ presented in TABLE $\mathrm{l}$ is the average value obtained from several time-displacement analyses.

Although initial estimates, described below, were made of the values of the remaining parameters $\left(A_{1}, A_{2}, A_{3}, M_{1}, M_{2}, J_{1}, J_{2}\right.$, $\mathrm{J}_{3}$, and $\mathrm{K}_{3}$ ), the estimated values were subject to adjustment in order to achieve reasonable agreement between the computed and measured responses of the animal as illustrated in FIGURES 2, 11 , and 12 .

Assuming negligible air flow to and from the lungs and neglecting the stiffness of the mechanical spring, the velocity resonant frequency of the chest wall can be estimated (Bowen et al., 1965) by

$$
f_{V}=1 /(2 \pi) \sqrt{\gamma A_{i}^{2} P /\left(V_{i} M_{i}\right)}
$$

where $f_{\mathrm{V}}$ is the velocity resonant frequency; $\gamma$, the polytropic exponent (assumed to be 1.2); $P$, the average pressure in the lungs, or the local ambient pressure about which oscillations occur; and $V_{i}, A_{i}$, and $M_{i}$ 
are lung volume, piston area, and piston mass, respectively, defined in FIGURE 1. If the a rea density of the chest wall

$$
\rho_{\mathrm{a}}=\mathrm{M}_{\mathrm{i}} / \mathrm{A}_{\mathrm{i}}
$$

is introduced in Eq. (A2), an explicit solution can be obtained for a rea

$$
A_{i}=4 \pi^{2} f_{v}^{2} V_{i} \rho_{a} /(\gamma P)
$$

Initial estimates were made for the areas and masses of the chestwall pistons using in Eqs. (A3) and (A4) an a rea density reported for rabbits (Clemedson and Jönsson, 1964) and a resonant frequency reported for dogs (von Gierke, 1964) - both scaled to a $10-\mathrm{kg}$ animal.

The effective area, $A_{3}$, and spring constant, $K_{3}$, of the middle piston were chosen so that the area density and spring constant per unit mass, respectively, would be approximately the same for this piston as for the others.

For a given lung volume, the damping factors along with the piston areas and masses are the most significant factors determining the response of the model to a given blast wave or missile impact. These parameters were adjusted until the magnitude and time of the computed peak intrathoracic overpressures agreed reasonably well with measured values as illustrated in FIGURE 2. The area of the right chest-wall piston for missile impact was determined by trial and error, the value determined being somewhat larger than the actual impact area of the missile but smaller than the area effective in the blast situation. 


\section{DISTRIBUTION}

\section{ARMY AGENCIES}

Chief of Research and Development, Life Sciences Division, Dept. of the Army, ATTN: CRDLS, Washington, D. C. 20310 (1 copy)

Chief of Research and Development, Dept. of the Army, ATTN: CRDNCB, Washington, D. C. 20310 (1 copy)

Assistant Chief of Staff for Intelligence, Dept. of the Army, ATTN: DFISS, Washington, D. C. 20310 (1 copy)

Chief of Engineers, Department of the Army, ATTN: ENGTE-E, Washington, D. C. 20315 (1 copy)

Directorate of Transportation, U.S. Army Materiel Cmd., Washington, D. C. 20315 (1 copy)

Commanding General, Medical Research and Development Cmd., Dept. of the Army, ATTN: MEDDH-N, Main Navy Building, Washington, D. C. 20360 (2 copies)

Commanding General, Medical Research and Development Cmd., Dept. of the Army, ATTN: MEDPS-CS, Main Navy Bldg., Washington, D. C. 20360 (2 copies)

Commanding General, Medical Research and Development Command, Dept. of Army, ATTN: MEDDH-RS, Main Navy Bldg., Washington, D. C. 20360 (2 copies)

U.S. Army CDC Artillery Agency, Fort Sill, Oklahoma 73503 (1 copy)

President, Aviation Test Board, U. S. Army Aviation Center, Fort Rucker, Alabama 36362 (1 copy)

Assistant Chief of Staff for Force Development, Dept. of the Army, ATTN: Directorate of CBR and Nuclear Operations, Washington, D. C. 20310 (1 copy)

Commandant, U.S. Army C\&GS College, ATTN: Archives, Fort Leavenworth, Kansas 66027 (1 copy)

Commandant, U.S. Army Air Defense School, ATTN: Command \& Staff Dept., Fort Bliss, Texas 79906 (1 copy)

Commanding Officer, U.S. Army CDC Armor Agency, Fort Knox, Kentucky 40120 (1 copy)

Commanding Officer, U.S. Army CDC Artillery Agency, Fort Sill, Oklahoma 73503 (1 copy)

Commanding Officer, U.S. Army CDC Infantry Agency, Fort Benning, Georgia 31905 (1 copy)

Commanding Officer, U.S. Army CDC CBR Agency, Fort McClellan, Alabama 36205 (1 copy)

Commandant, U.S. Army CBR, Weapons School, Dugway Proving Ground, Dugway, Utah 84022 (1 copy)

Commanding General, Army Medical Service School, Brooke Army Medical Center, ATTN: DCCO, Fort Sam Houston, Texas 78234 (1 copy)

Commanding General; The Engineer Center, ATTN: Asst Cmdt Engineer School, Fort Belvoir, Virginia 22060 (1 copy)

Commanding General, 9th Hospital Center, ATTN: CO, U.S. Army Nuclear Medicine Research Det., Europe, APO New York 09180 (1 copy)

Commanding Officer, U.S. Army Chemical Research and Development Lab. , Edgewood Arsenal, Maryland 21040 (1 copy)

Commandant, Walter Reed Army Institute of Research, Walter Reed Army Medical Center, Washington, D. C. 20012 (5 copies)

Commanding General, U.S. Army Natick Laboratories, ATTN: Technical Library, Natick, Massachusetts 01760 (1 copy) 
Commanding Officer, U.S. Army, Combat Development Cmd., Institute of Nuclear Studies, Fort Bliss, Texas 79906 (1 copy)

Commanding General, U.S. Army Combat Development Cmd., ATTN: CDC CD-F, Fort Belvoir, Virginia 22060 (2 copies)

Commanding General, U.S. Army, Combat Development Command, ATTN: Combat Support Group, Fort Belvoir, Va 22060 (1 copy)

Commanding Officer, U.S. Army, Combat Development Cmd, Medical Service Agency, Fort Sam Houston, Texas 78234 (1 copy)

Commanding General, U.S. Army, Combat Development Cmd, Combat Arms Group, Fort Leavenworth, Kansas 66027 (1 copy)

Director Armed Forces Institute of Pathology, Walter Reed Army Medical Center, 625 16th Street, N. W., Washington, D. C. 20012 (1 copy)

Director, Waterways Experiment Station, P. O. Box 631, ATTN: Library, Vicksburg, Mississippi 39180 (1 copy)

Director, U.S. Army Ballistic Research Laboratories, Aberdeen Proving Ground, Maryland 21005 (2 copies)

Redstone Scientific Info Center, U.S. Army Missile Cmd, ATTN: Chief, Document Section, Redstone Arsenal, Alabama 35808 (1 copy)

Commanding General, Army Materiel Command, ATTN: AMCRD-BN, Washington, D. C. 20315 (1 copy)

Commanding Officer, U.S. Army Nuclear Defense Laboratory, ATTN: Librarian, Edgewood Arsenal, Maryland 21040 (1 copy)

Commanding General, Army Materiel Command, ATTN: EOD Division, Washington, D. C. 20315 (1 copy)

Office of the Secretary of the Army, Assistant Director of OCD, ATTN: Research, Washington, D. C. 20310 (5 copies)

\section{NAVY AGENCIES}

Chief of Naval Operations, Navy Department, ATTN: OPO3EG, Washington, D. C. 20350 (1 copy)

Chief of Naval Operations, Navy Department, ATTN: OP-75, Washington, D. C. 20350 (1 copy)

Chief of Naval Operations, Navy Department, ATTN: OP-922G2, Washington, D. C. 20350 (1 copy)

Chief of Naval Personnel, Tech Library, Code 11B, Navy Department, Washington, D. C. 20370 (1 copy)

Chief of Naval Research, Navy Department, ATTN: Code 811, Washington, D. C. 20390 (1 copy)

Chief, Bureau of Medicine and Surgery, Navy Department, ATTN: Code 74, Washington, D. C. 20390 (2 copies)

Chief, Bureau of Medicine and Surgery, Navy Department, ATTN: Code 71, Washington, D. C. 20390 (1 copy)

Chief, NAVSHIPS, Navy Department, ATTN: Code 423, Washington, D. C. 20390 (1 copy)

Chief, NAVSHIPS, Navy Department, ATTN: Code 364, Washington, D. C. 20390 (1 copy)

Director, U.S. Naval Research Laboratory, Washington, D. C. 20390 (1 copy)

Commander, U.S. Naval Ordnance Laboratory, White Oak, Maryland 20910 (1 copy)

CO, U.S. Naval Mine Defense Laboratory, Panama City, Florida 32401 (1 copy)

CO, U.S. Naval Unit, U.S. Army Chemical School, Fort McClellan, Alabama 36205 (1 copy) 
Nuclear Medicine Division, School of Submarine Medicine, U.S. Naval Submarine Medical Center, Box 600, U.S. Naval Submarine Base, New London, Groton, Connecticut 06340 (1 copy)

CO, U.S. Naval Hospital, ATTN: Director, REEL, NNMC, Bethesda, Md. 20014 (1 copy)

CO and Director, U.S. NRDL, ATTN: Tech Info Div, San Francisco, California 94135 (4 copies)

CO, Nuclear Weapons Training Center, Atlantic, U.S. Naval Base, ATTN: Nuclear Warfare Department, Norfolk, Virginia 23511 (1 copy)

$\mathrm{CO}$, Nuclear Weapons Training Center, Pacific, U.S. Naval Air Station, North Island, San Diego, California 92135 (1 copy)

CO, U.S. Naval Damage Control Training Center, Naval Base, ATTN: NBC Defense Course, Philadelphia, Pennsylvania 19112 (1 copy)

Superintendent, U.S. Naval Postgraduate School, Monterey, California 93940 (1 copy)

U.S. Naval Schools Command, T. I., NBC Defense Dept., Box 104, Bldg 194, ATTN: Tech Library, San Francisco, California 94130 (1 copy)

Commanding Officer, U.S. Naval Air Development Center, ATTN: NAS, Librarian, Johnsville, Pennsylvania 18974 (1 copy)

Officer in Charge, U.S. Naval Supply Research and Development Facility, Naval Supply Center, Bayonne, New Jersey 07002 (1 copy)

Commanding Officer, U.S. Naval Medical Research Institute, National Naval Medical Center, Technical Reference Library, Bethesda, Maryland 20014 (2 copies)

Commandant, U.S. Marine Corps, ATTN: Code A03H, Washington, D. C. 20380 (1 copy)

U. S. Naval School of Aviation Medicine, U.S. Naval Aviation Medical Center, ATTN: Director of Research, Pensacola, Florida 32508 (1 copy)

Commanding Officer, U.S. Naval Weapons Laboratory, Dahlgren, Virginia 22448 (1 copy) David Taylor Model Basin, Code 258, Washington, D. C. 20007 (2 copies)

Commander, Naval Facilities Engineering Command, Department of the Navy, Washington, D. C. 20390 (1 copy)

Commander, U.S. Naval Applied Science Laboratory (Code 900), Naval Base, Brooklyn, New York 11251 (1 copy)

U. S. Naval Ordnance Test Station, Code 4563, China Lake, California 93555 (2 copies)

AIR FORCE AGENCIES

HQ USAF (1 copy)

HQ USAF (AFMSPA) T-8, Wash DC 20333 (1 copy)

HQ USAF (AFMSR), T-8, Wash DC 20333 (1 copy)

HQ USAF, Chief of Operations and Analysis, Wash DC 20330 (1 copy)

HQ USAF (AFRSTA), Wash DC 20330 (1 copy)

HQ USAF (AFTAC), 6801 Telegraph Road, Alexandria, Va. 22310 (1 copy)

HQ USAF (AFRDD), Wash DC 20330 (1 copy)

\section{AIR FORCE. MAJOR COMMANDS}

AFSC (SCS-7), Andrews AFB, Wash DC 20331 (1 copy)

AFSC (SCB), Andrews AFB, Wash DC 20331 (1 copy)

AFSC (SCTR), Andrews AFB, Wash DC 20331 (1 copy)

ADC, Asst for Atomic Energy, ADLDCA, Ent AFB, Colorado 80912 (1 copy)

AUL, Maxwell AFB, Alabama 36112 (1 copy)

SAC (OA), Offutt AFB, Nebraska 68113 (1 copy)

SAC (SUP), Offutt AFB, Nebraska 68113 (1 copy) 
TAC (OA), Langley AFB, Virginia 23365 (1 copy)

AU, Office of the Surgeon, Maxwell AFB, Alabama 36112 (1 copy)

ATC, Office of the Surgeon, Randolph AFB, Texas 78148 (1 copy)

\section{AFSC ORGANIZATIONS}

AFSC Scientific and Tech Liaison Office, RTD, ATTN: AFUPO, Los Angeles, California 90045 (1 copy)

HQ, RTD (RTTW), Bolling AFB, Wash DC 20332 (1 copy)

HQ, FTD (TDFBD), Wright-Patterson AFB, Ohio 45433 (1 copy)

HQ, BSD (BSR-1), Norton AFB, California 92409 (1 copy)

HQ, ASD (ASMM), Wright-Patterson AFB, Ohio 45433 (1 copy)

HQ, RTD(SEG/SENS), Wright-Patterson AFB, Ohio 45433 (1 copy)

AFAPL(APS), Wright-Patterson AFB, Ohio 45433 (1 copy)

AFAL(AVS), Wright-Patterson AFB, Ohio 45433 (1 copy)

AFML(MAS), Wright-Patterson AFB, Ohio 45433 (1 copy)

HQ SSD(SSTR), AFUPO 45, Los Angeles, California 90045 (1 copy)

RADC(EMEAM), Griffiss AFB, NY 13440 (1 copy)

AFWL(WLR), Kirtland AFB, New Mexico 87117 (1 copy)

AFRPL(RPPP), Edwards AFB, California 93523 (1 copy)

HQ ESD (ESLE), L. G. Hanscom Fld, Bedford, Mass. 01731 (1 copy)

HQ AMD (AMR), Brooks AFB Tex 78235 (1 copy)

HQ AMD (AMRB), Brooks AFB Tex 78235 (1 copy)

HQ AMD (AMRO), Brooks AFB Tex 78235 (1 copy)

AFSWC (SWLA), Kirtland AFB NMex 87117 (1 copy)

AFWL (WLIL), Kirtland AFB NMex 87117 (1 copy)

AFWL (WLRB), Kirtland AFB NMex 87117 (2 copies)

USAF SAM (SMB), Brooks AFB Tex 78235 (1 copy)

6570 AMRL, Wright-Patterson AFB, Ohio 45433 ( 2 copies)

6571 ARL, Holloman AFB NMex 88330 (1 copy)

\section{OTHER AIR FORCE AGENCIES}

AFCRL, ATTN: CRQST-2, L. G. Hanscom Fld, Bedford, Mass. 01731 (1 copy)

Director, USAF Project Rand, AF Liaison Officer, Rand Corp (Library), 1700 Main St. , Santa Monica, California 90401 (1 copy)

Medical Service School (Rad Branch), Sheppard AFB Tex 76311 (1 copy)

HQ OAR (RROS), 1400 Wilson Blvd, Arlington, Virginia 22209 (1 copy)

AFOSR (SRGL), 1400 Wilson Blvd, Arlington, Virginia 22209 (1 copy)

AFIT (Tech Library), Wright-Patterson AFB, Ohio 45433 (1 copy)

Air Force Western Test Range (WTOSM), Vandenberg AFB, California 93437 (1 copy)

\section{DEPARTMENT OF DEFENSE AGENCIES}

DDC, Cameron Station, Alexandria, Virginia 22314 (20 copies)

Director of Defense Research and Engineering, ATTN: Tech Library, Washington; D. C. 20301 (1 copy)

Director of Defense Research and Engineering, ATTN: Chief, Medical Services Division, Office of Science, Washington, D. C. 20301 (1 copy)

Director, Defense Atomic Support Agency, ATTN: Document Library, Washington, D. C. 20301 (3 copies) 
Director, Defense Atomic Support Agency, ATTN: STMD (For TTCP), Washington, D. C. 20301 (12 copies)

Commander, Test Command, Defense Atomic Support Agency, Sandia Base, Albuquerque, New Mexico 87115 (1 copy)

Commander, Field Command, Defense Atomic Support Agency, Sandia Base, ATTN: Surgeon, Albuquerque, New Mexico 87115 (1 copy)

Commander, Field Command, Defense Atomic Support Agency, ATTN: FCTG, Albuquerque, New Mexico 87115 (1 copy)

Director, Armed Forces Radiobiology Research Institute, National Naval Medical Center, Bethesda, Maryland 20014 (2 copies)

Director, Weapons Systems Evaluation Group, Washington, D. C. 20305 (1 copy)

U.S. Documents Officer, Office of the United States National Military RepresentativeSHAPE, APO, New York, New York 09055 (1 copy)

Director, Armed Forces Institute of Pathology, Walter Reed Army Medical Center, Washington, D. C. 20012 (1 copy)

Director, ARPA, DOD, ATTN: Tech Info Officer, the Pentagon, Washington, D. C. 20301 (1 copy)

Director, DIA, ATTN: DIAAP-IKZ, Washington, D. C. 20301 (1 copy)

\section{OTHER FEDERAL AGENCIES}

Atomic Energy Commission, ATTN: Asst. Director for Medicine \& Health Research, DBM, Washington, D. C. 20545 (1 copy)

Atomic Energy Commission, Civil Effects Branch, Div of Biology and Medicine, Washington, D. C. 20545 (150 copies)

Atomic Energy Commission, Div of Technical Information Extension, P. O. Box 62, Oak Ridge, Tenn. 37830 (300 copies)

Director, National Aeronautics \& Space Admin., Washington, D. C. 20546 (1 copy)

National Aeronautics and Space Admin., ATTN: Director, Life Sciences Program, Washington, D. C. 20546 (1 copy)

National Library of Medicine, Accessions Branch, 8600 Wisconsin Ave., Bethesda, Maryland 20014 (1 copy)

Federal Air Surgeon, (AM-1) HQ Federal Aviation Agency, 800 Independence Ave., S. W. , Washington, D. C. 20553 (1 copy)

Public Health Service, 4th and Jefferson Drive, S. W. , Washington, D. C. 20201 (1 copy)

Public Health Service, Southwest Radiological Health Lab., ATTN: Tech Library, P. O. Box 684, Las Vegas, Nevada 89101 (1 copy)

USPHS, Research Branch, Division of Radiological Health, 1901 Chapman Av. , Rockville, Md. 20853 (1 copy)

USPHS, S. E. Radiobiology Health Laboratory, PO Box 61, Montgomery, Alabama 36101 (1 copy)

Lawerence Radiation Lab., U. of Calif., P. O. Box 808, ATTN: Information Integration Group, Livermore, California 94550 (1 copy)

Argonne National Laboratory, 9700 South Cass Ave., ATTN: Medical Div., Argonne, Illinois 60440 (1 copy)

Batelle N.W. Laboratory, P. O. Box 999, ATTN: Dr. Bair, Rickland, Washington 99352 (1 copy)

Brookhaven National Laboratory, Tech Information Div., Documents Group, Upton, New York 14100 (1 copy)

Los Alamos Scientific Laboratory, ATTN: Biomedical Research Group, P. O. Box 1663, Los Alamos, New Mexico 87544 (1 copy) 
Lawrence Radiation Laboratory, U. of California, P. O. Box 808, ATTN: Biomedical Research Div., Livermore, California 94550 (1 copy)

\section{NON FEDERAL AGENCIES}

National Academy of Sciences, ATTN: Richard Park, 2101 Constitution Ave., Washington, D. C. 20418 (5 copies)

Eric H. Wang Civil Engineering Research Facility, Box 188, University Station, U. of New Mexico, Albuquerque, New Mexico 87106 (1 copy)

Southwest Research Institute, ATTN: Technical Library, 8500 Culebra Road, San Antonio, Texas 78228 (1 copy)

Medical College of So. Carolina, Dept of Surgery, ATTN: Dr. M. S. Rittenbury, 55 Doughty St. , Charleston, So. Carolina 29403 (1 copy)

Cincinnati General Hospital, Radioisotope Lab., ATTN: Dr. E. L. Saenger, Cincinnati, Ohio 45229 (1 copy)

New York State Veterinary College, Cornell U., Dept. of Physical Biology, ATTN: Dr. Comar, Ithaca, New York 14850 (1 copy)

Lovelace Foundation for Medical Education \& Research, 5200 Gibson Blvd., S. E., ATTN: Dr. C. S. White, Albuquerque, New Mexico 87108 (50 copies)

The Rand Corporation, 1700 Main St. , Santa Monica, Calif. 90401 (1 copy)

U. of Rochester, School of Medicine \& Dentistry, Dept of Radiation Biology, P. O. Box 287, Station 3, Rochester, New York 14620 (1 copy)

U. of Rochester, P. O. Box 287, Station 3, ATTN: Atomic Energy Project Library, Rochester, New York 14620 (1 copy)

U. of New Mexico, ATTN: Library, Albuquerque, New Mexico 87106 (1 copy)

U. of Pennsylvania Medical School, Medical Library, ATTN: Librarian for Blast Biology, Philadelphia, Penn. 19104 (1 copy)

San Francisco State College, 1600 Holloway Ave., ATTN: Dr. Curtis Newcombe, San Francisco, Calif 94132 (1 copy)

Baylor University, ATTN: Document Library, 5th and Speight, Waco, Texas 76703 (1 copy)

University of California, ATTN: Director Radiobiology Lab., Davis, California 95616 (1 copy)

Laboratory of Nuclear Medicine \& Radiation Biology School of Medicine, U. of Calif. , ATTN: Library, 900 Veteran Ave., Los Angeles, Calif 90024 (1 copy)

Colorado State University, ATTN: Dir Collaborative Radiological Health Laboratory, Ft. Collins, Colo 80521 (1 copy)

Mass Institute of Technology, ATTN: MIT Library, Cambridge, Mass 02139 (1 copy)

Polaroid Corp, ATTN: Tech Library, 119 Windsor St., Cambridge, Mass 02139 (1 copy)

Medical College of Virginia, ATTN: Dept of Biophysics, 523 N. 12th St. , Richmond, Virginia 23219 (1 copy)

Sandia Corporation, P. O. Box 5800, ATTN: Dir of Research, Albuquerque, New Mexico 87115 (2 copies) 


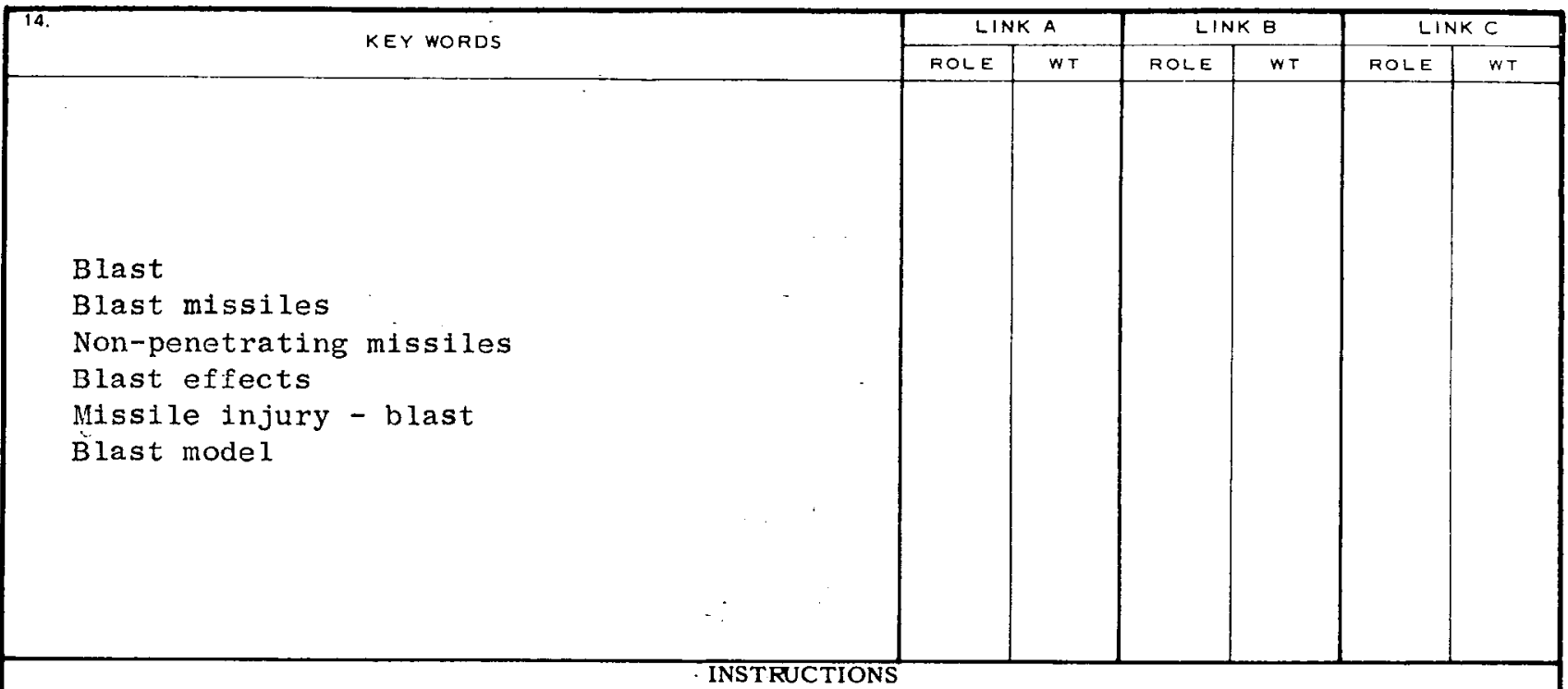

1. ORIGINATING ACTIVITY: Enter the name and address of the contractor, subcontractor, grantee, Department of Defense activity or other organization (corporate author) issuing the report.

2a. REPORT SECURTY CLASSIFICATION: Enter the overall security classification of the report. Indic ate whether "Restricted Data" is included. Marking is to be in accordance with appropriate security regulations.

2b. GROUP: Automatic downgrading is specified in DoD Directive 5200.10 and Armed Forces Industrial Manual. Enter the group number. Also, when applicable, show that optional markings have been used for Group 3 and Group 4 as authorized.

3. REPORT TITLE: Enter the complete report title in all capital letters. Titles in all cases should be unclassified. If a meaningful title cannot be selected without classification, show title classification in all capitals in parenthesis immediately following the title.

4. DESCRIPTIVE NOTES: If appropriate, enter the type of report, e.g., interim, progress, summary, annual, or final. Give the incl usive dates when a specific reporting period is covered.

5. AUTHOR(S): Enter the name(s) of author(s) as shown on or in the report. Enter last name; first name, middl e initial. If military, show rank and branch of service. The name of the principal author is an absolute minimum requirement. 6. REPORT DATE: Enter the date of the report as day, month, year; or month; year. If more than one date appears on the report, use date of publication.

7a. TOTAL NUMBER OF PAGES: The total page count should follow nomal pagination procedures, i. e.; enter the number of pages containing information.

7b. NUMBER OF REFERENCES Enter the total number of references cited in the report.

8a. CONTRACT OR GRANT NUMBER: If appropriate, enter the applicable number of the contract or grant under which the report was written.

$8 b, 8 c, 8 d 8$. PROJECT NUMBER: Enter the appropriate military department identificattion, such as project number, subproject number," system numbers, task number, etc.

9a. ORIGINATOR'S REPORT NUMBER(S): Enter the official report number by which the document will be identified. and controlled by the originating activity. This number must be unique to this report.

$9 b$. OTHER REPORT NUMBER(S): If the report has been assigned any other report numbers (either by the originator or by the sponsor), al so enter this number(s).
10. AVALLABILITY/LIMITATION NOTICES: Enter any limitations on further dissemination of the report, other than those imposed by security classification, using standard statements such as:

(1) "Qualified requesters may obtain copies of this report from DDC."

(2) "Foreign announcement and dissemination of this report by DDC is not authorized."

(3) "U. S. Government agencies may obtain copies of this report directly from DDC. Other qual ified DDC users shall request through

(4) "U. S. military agencies may obtain copies of this report directly from DDC. Other qualified users shall request through

(5) "All distribution of this report is controlled. Qualified DDC users shall request through ."

If the report has been furnished to the Office of Technical Services, Department of Commerce, for sale to the public, indicate this fact and enter the price, if known

11. SUPPLEMENTARY NOTES: Use for additional explanatory notes.

12. SPONSORING MILITARY ACTIVITY: Enter the name of the departmental project office or laboratory sponsoring (paying for) the research and development. Include address.

13. ABSTRACT: Enter an abstract giving a brief and factual summary of the document indicative of the report, even though it may also appear elsewhere in the body of the technical report. If additional space is required, a continuation sheet shall be attached.

It is highly desirable that the abstract of classified reports be unclassified. "Each paragraph of the abstract shall end with an indication of the military security classification of the information in the paragraph, represented as (TS), (S), (C), or $(U)$.

There is no limitation on the length of the abstract. How ever, the suggested length is from 150 to 225 words.

14. KEY WORDS: Key words are technically meaningful terms or short phrases that characterize a report and may be used as index entries for cataloging the report. Key words must be selected so that no security classification is required. Idenfiers, such as equipment model designation, trade name, military project code name, geographic location, may be used as key words but will be followed by an indication of technical context. The assignment of links, rules, and weights is optional. 
Security Classification

DOCUMENT CONTROL DATA - R\&D

(Security clasaification of tille, body of abstract and indexing ennotation must be entered when the overall report is classified) 1. ORIGINATING ACTIVITY (Comporate author)

Lovelace Foundation for Medical Education \& Research Albuquerque, New Mexico 87108

2a. REPORT SECURITY CLASSIFICATION UNCLASSIFIED

2b. GROUP

3. REPORT TITLE

Biophysical Mechanisms and Scaling procedures Applicable in Assessing Response of the Thorax Energized by Air-Blast Overpressures or by Non-Penetrating Missiles

4. DESCRIPTIVE NOTES (Type of report and inclusive detes)

Progress

5. AUTHOR(S) (Last name. first name, initial)

Bowen, I.G.; Fletcher, E.R.; Richmond, D.R.; H1rsch, F.G.; White, C.S.

\begin{tabular}{|c|c|c|}
\hline $\begin{array}{l}\text { 6. REPORT DATE } \\
\text { November } 66 \\
\end{array}$ & $\begin{array}{c}\text { 7a. TOTAL NO. OF PAGES } \\
46 \\
\end{array}$ & $\begin{array}{r}\text { b. NO. OF REFS } \\
26 \\
\end{array}$ \\
\hline $\begin{array}{l}\text { 8a. CONTRACT OR GRANT NO. } \\
\text { DA-49-146-XZ-372 } \\
\text { b. PROJECT NO. } \\
\text { O3.012 }\end{array}$ & $\begin{array}{l}\text { 9A. ORIGINATOR'S REPORT } \\
\text { DASA } 1857\end{array}$ & $B \in R(S)$ \\
\hline $\begin{array}{l}\text { c. } \\
\text { d. }\end{array}$ & 9b. OTHER REPORT NO(S) & other numbers that may bo assigned \\
\hline
\end{tabular}

\begin{tabular}{|l|l}
\hline 11. SUPPLEMENTARY NOTES & 12. SPONSORING MILITARY ACTIVITY
\end{tabular}

DASA

13. ABSTRACT

A mathematical model was described which was devised to study the dynamic response of the thorax of mammals to rapid changes in environmental pressure and to non-penetrating missiles impacting the rib cage near the mid-lateral point of the right or left thorax. Scaling procedures for similar animals were described relating, for a given degree of damage, the body mass of the animal to various parameters describing the exposure "dose".

Internal pressures computed with the model for a dog exposed at the end plate of a shock-tube were compared to those measured with a pressure transducer inserted in the esophagus down to the level of the heart.

Computed time-displacement histories of missiles following impact with the right side of the thorax were compared to those obtained experimentally by means* of high-speed motion picture photography. High internal pressures predicted with the model for non-penetrating impact were compared to those obtained experimental$1 \mathrm{y}$ and theoreticaliy for exposure to air blast.

Experimental data were presented arbitrarily assessing lung damage in animals struck by non-penetrating missiles (constant impact area) as a function of missile mass and impact velocity. These data were compared for several missile massvelocity combinations with those computed using the mathematical model. Similarities in the dynamic responses of the thorax to air blast and to non-penetrating missiles were discussed.

DD , FORM 1473

Security Classification 